Egyptian Poultry Science Journal

http://www.epsaegypt.com

ISSN: 1110-5623 (Print) - 2090-0570 (On line)

\title{
EFFECT OF DIFFERENT LEVELS AND SOURCES OF DIETARY FIBER ON PRODUCTIVE AND ECONOMIC PERFORMANCE OF LOCAL LAYING HENS 2- DURING LAYING PERIOD
}

\author{
A.G. Abdallah; M.M. Beshara and Y.S. Rizk \\ Anim. Prod. Res. Instit., Agric. Res. Center, Minis. of Agric. Dokki, Giza.
}

Received: 24/ 01/2016

Accepted: 08/02/2016

\begin{abstract}
A total number of 198 local Sinai laying hens (180 female + 18 males), 24weeks-old, were weighed and divided into six dietary treatments to investigate the effect of dietary different levels and sources of crude fiber on productive and reproductive performance and nutrients digestibility during the laying period (24-40 weeks of age). The birds were fed a control diet contained $3.5 \%$ crude fiber (CF) while, the remaining treatments were given moderate levels of dietary crude fiber by suing different levels of sunflower meal (SFM) and olive cake (OK). Results obtained could be summarized in the following:
\end{abstract}

1. The different levels of CF had significantly higher BW and CBW comparing with the control diet $(3.2 \% \mathrm{CF})$ except for the diet contained $5.42 \% \mathrm{CF}(8 \% \mathrm{OK})$.

2. The inclusion of different fiber levels in the diets resulted in significantly decreased egg number/hen, while egg weight was significantly improved for the all dietary CF treatments compared to the control diet except for the diet contained $5.42 \% \mathrm{CF}$ where it did not actually differ from control diet.

3. Regarding to egg mass, no significant differences were found between the group fed diet contained $5.6 \% \mathrm{CF}$ and the control diet.

4. Feed conversion ratio was significantly lower for the birds fed diets with different levels of CF than control.

5. Diet containing $4.42 \% \mathrm{CF}(7 \% \mathrm{SFM})$ resulted in a significant higher hatchability of set eggs compared to control and other treatments. In addition, the hatchability of fertile eggs tends to significantly increase in treatments fed 4.45, 4.42 and 5.6\% CF (7\% SFM, $4 \% \mathrm{OK}$ and $7 \% \mathrm{SFM}+4 \% \mathrm{OK}$ ) as compared to the control diet.

6. Embryonic mortality significantly decreased by the diets contained 4.45, 4.42 and $5.6 \% \mathrm{CF}$ compared to control group meanwhile the other treatment did not actually differ from control diet.

7. All different levels of CF resulted in a significantly higher crude fiber and ether extract digestibility than control diet.

Key Words: Dietary fiber, Sunflower meal, Olive cake, Laying performance Fertility.

Corresponding author: malakman88@yahoo.com 
8. No significant influence of different levels of dietary crude fiber during the laying period at 40 weeks of age on the relative weight of sections of GIT segments and relative length of small intestine.

9. Hens fed diet with 5.6 \% CF- tend to have greater HDL \% than control, also, all treatments tend to have higher HDL/LDL than those fed 3.2\% CF (control diet).

10. No significant effect on economic efficiency of egg production due to the diet contained 5.66\% CF (14\%SFM) compared to the control diet.

The current study illustrated that moderate levels of CF in this study can be used to reduce the embryonic mortality and enhance hatchability and chick weight at hatch without any harmful impact on EE of hatchability except for the diet with $4.42 \%$ CF (4\% Ok) also, without any detrimental effects on egg weight, egg mass, egg quality and EE of egg production in respect of the diets contained $5.66 \% \mathrm{CF}(14 \% \mathrm{SFM})$ and $5.6 \%$ $\mathrm{CF}(7 \% \mathrm{SFM}+4 \% \mathrm{OK})$.

\section{INTRODUCTION}

Feed cost has been reported to account for $60-80 \%$ of total production cost in any system of poultry production. In Egyptincreasing ingredients prices remain the greatest single item that determines profit margins in poultry production. Fiber is nutritionally, chemically and physically heterogeneous material, which can be categorize into two major subclasses i.e., viscous and fermentable fiber (soluble) and non-viscous and non-fermentable fiber (insoluble). Both the subclasses have different roles in the digestive and absorptive processes within the gastrointestinal tract. Differentiation of soluble and insoluble fiber components can help elucidates the physiological effects of fiber (Newman et al., 1992). Traditionally, in most research conducted on poultry feeding, dietary fiber has been considered a diluent of the diet (Rougière, and Carré., 2010)with negative connotations in relation to voluntary feed intake and nutrient digestibility (Svihus, 2011). However, according to research conducted in recent years, dietary fiber content, have an important place in well balanced diets where, the inclusion of moderate amounts of different fiber sources in the diet improves digestive organ development (González-Alvarado et al., 2007 and Hetland and Svihus 2007) and increases $\mathrm{HCl}$, bile acids, and enzyme secretion
(Hetland et al., 2003). These changes might result in improvements in nutrient digestibility (Amerah et al., 2009) gastrointestinal tract health (Montagne et al., 2003), and eventually, animal welfare (Aerni et al., 2000 and Van Krimpen et al., 2009). Some researchers have indicated that an adequate type and amount of fiber might improve gastro intestinal tract adaptation of poultry to current productive systems and reduce digestive disturbances without antibiotic use in feed (Mateos et al., 2002; Montagne et al., 2003). Insoluble fiber can affect the gut transit time of digesta, gut motility of epithelium and may improve the ability of endogenous enzymes to successful access to their related substrates (Choct, 2001). This indicates a need for structural components in response to the lack of fiber in poultry diets (Hetland et al., 2005).Although, soluble fibers increase viscosity and affect negatively nutrient digestion and absorption (Smits and Annison, 1996). But, the ratio of insoluble to soluble fiber in a dietary fiber source can affect overall diet utilization and appears to be important in the formulation of diets to provide optimal efficacy (Burhalter et al., 2001).

The study conducted by Incharoen and Maneechote (2013) indicated that whole rice hull can be used as a source of insoluble fiber in diets up to $6 \%$ to enhance growth and uniformity of pullet chicks and 
to improve egg production of laying hens without any harmful impact on egg quality. The presence of fiber in the gizzard, especially when highly insoluble and lignified coarsely ground fiber is used, stimulates organ functioning. In fact, the inclusion of dietary fiber consistently reduces $\mathrm{pH}$ in the gizzard, and a reduction in digesta $\mathrm{pH}$ benefits pepsin activation and solubility of the mineral sources (Van der Aar et al., 1983). There is relationship between the proventriculus and gizzard thus it is tempting to suggest that the secretion of $\mathrm{HCl}$ and pepsinogen in the proventriculus will depend on the functionality of the gizzard, including the intensity of the contractions and retention time (Svihus 2011). In addition, the increased grinding activity of the gizzard, together with a better mixing of digestive juices with the digesta attributable to the increase in antiperistaltic movements within the gastrointestinal tract, might explain the positive effects of insoluble dietary fiber on the digestibility of crude protein and other dietary components (Jiménez-Moreno et al., 2009).Feeding diet with insoluble raw fiber concentrate did not influence egg quality parameters and size and weight of the GIT (Victor et al., 2013). Hartini et al. (2002) compared a commercial laying hen diet based contained $2.9 \% \mathrm{CF}$ with diets that included a crude fiber source. They observed that mortality was reduced with the inclusion of fiber in the diet. Results of the study by Roberts et al. (2007) showed that inclusion of different sources of CF such as soybean hulls in laying-hen diets had no adverse effects on egg production, egg quality, or $\mathrm{N}$ balance. The beneficial effects of dietary fiber on nutrient digestibility varied with the source and level of dietary fiber as well as with the composition of the basal diet. Thus, the beneficial effects of fiber inclusion on the productive performance of laying hens were related to improved nutrient digestibility rather than to changes in the metabolic pathways.
The high costs of the alternative soybean protein sources prompted interest in other high-protein feed ingredients including sunflower meal (SFM). In contrast to soybean meal (SBM), sunflower meal (SFM) contains lower quantities of anti nutritional compounds (Canibe et al., 1999). SFM is a well-established and relatively inexpensive protein source for poultry diets. In addition, it can be harvested two or three times a year in tropical areas, being a good alternative for oil producers and for the feed mill sector (Vieira et al., 1992). But, the use of SFM in poultry diets is limited by variations in its chemical composition, and the two main components apparently restricting its use are high fiber/low energy and low lysine contents (Senkoylu and Dale 1999). However, a significant relationship was observed between the water-soluble xylose content of the soybean meals and the improvement in weight gain obtained when sunflower meal replaced some of the soybean meal. Kalmendal et al. (2011) reported that the inclusion of up to $30 \%$ high fiber sunflower meal in a pelleted corn basal diet resulted in significant linear increases in apparent ileal digestibility of fat and CP but that DM and energy digestibility decreased. In addition, the same author reported that the inclusion in the diet of high levels of sunflower meal, an insoluble source of DF, was associated with significant decreases in colony counts of Clostridium spp. Casartelli et al. (2006) reported that SFM addition in commercial layer diets did not influence performance; however, increasing dietary SFM improved eggshell quality. Egg parameters were not affected by the SFM inclusion rate. According to the results of this experiment it can be concluded that 10 percent of high fiber sunflower meal can be used in laying hen diets without adverse effect on performance and egg parameters (Razaei and Hafezian 2007).

In respect of olive cake (OK), Sadeghi et al. (2009) reported that the inclusion of 
olive by-products as animal feed is undoubtedly a good way of recycling these waste products. According to M.A.L.R. (2004), there are 118,697 cultivated acres of olive trees in Egypt. Olive cake is the raw material (seed fractions) resulting from extraction of olive oil and the residual seeds from the industry of olive fruit reserve after mash the seed fractions where it included nearly $30 \%$ from the seeds. It has been reported that egg number and egg mass were significantly higher than of the control group when turkey fed diet containing 10 and $15 \%$ olive cake (Abdel Fadeel, 2006). Olive cake is considered as a good source of fat (18\% crude fat), for its level of residual oil, this can constitute a complementary energy source. For its particular composition of unsaturated fatty acids $(62.4 \%$ of oleic acid, $18.2 \%$ of linoleic acid, $1.1 \%$ of linolenic acid and $2.7 \%$ of palmitoleic acid (EI-Hachemi et al., 2007) olive cake could influence the accumulation of fatty acid in the various body compartments during the animal's life and as such could have a certain impact on the quality of egg. Therefore, the objectives of this study were to investigate the effects of dietary inclusion of different levels of crude fiber on the productive and reproductive performance of the Sinai laying hens during the laying period.

\section{MATERIALS AND METHODS}

\section{Bird's management and experimental diets:}

The experiment in the current study was conducted in El- Serw Poultry Research Station, Animal Production Research Institute, Agriculture Research Center, Ministry of Agriculture, Egypt. One hundred and ninety eight local Sinai laying hens (180 females and 18 males) at 24 weeks old were weighed and distributed into six treatments with three replicates per treatment (10 female and 1 male / replicate) based on adjusted body weight. Feed and fresh water were ad libitum during the experimental period, birds received 16 $\mathrm{h} /$ day of manipulated lighting. The experimental was started at 24 wks of age and ended at 40 wks of age, collected data were presented at 4-week interval periods.

Samples of sunflower meal and olive cake (part of pulp, seeds and embryo which include $30 \%$ of olive seeds) were taken to determine approximate analysis according to AOAC (1990) method. Acid detergent fiber (ADF) and neutral detergent fiber (NDF) were determined by Van Soest et al. (1991). Nitrogen free extract (NFE) was calculated by subtracting the sum of protein, ether extract, NDF from organic mater (OM) and the hemicelluloses content was calculated as a difference between ADF and ADF. The metabolizable energy (ME) of SFM and OK was calculated based on chemical composition according to equation NRC (1994) where:

$$
\begin{gathered}
\mathrm{ME}=36.63 \times \mathrm{CP}+77.96 \times \mathrm{EE}+19.87 \times \\
\text { NFE. }
\end{gathered}
$$

The approximate analysis of sunflower meal (SFM) and olive cake (OK) used in this study is presented in Table (1). Six experimental diets as shown in Table (2) were formulated as recommended by Hussein et al. (2010) to Sinai laying hens and all diets were formulated to provide the same levels of metabolizable energy and protein but it contained gradually levels of the crude fiber. Birds of control group were fed a basal diet with corn, and soybean as the main ingredients, the remaining treatments were given moderate levels of dietary crude fiber as a result of usage different levels of sunflower meal, olive cake and combination between them, because both SFM and OK are high crude fiber content thus the experimental diets were as follow: 1- control diet $(3.2 \% \mathrm{CF})$ 2- Diet with $4.45 \% \mathrm{CF}(7 \%$ SFM) 3- Diet with $5.66 \% \mathrm{CF}(14 \%$ SFM $)$ 4-Diet with $4.42 \%$ CF (4\% OK) 5- Diet with $5.42 \%$ CF (8\% OK). 6- Diet with $5.6 \%$ CF (7\% $\mathrm{SFM}+4 \% \mathrm{OK})$.

Productive, reproductive performance and egg quality: 
Feed intake of each replicate was recorded every 28 days in g/hen. Body weight (BW) was recorded at the beginning and at the end of the experiment. Egg production, egg mass, feed conversion ratio as feed consumed (g) / egg mass (g) were also determined. At two periods of the experimental study, 3 eggs /replicate were collected at random to measure egg quality. In addition, the reproduction traits which included fertility, and hatchability were measured at 36 weeks of age.

\section{Nutrients digestibility and nitrogen retention:}

Digestion trial were done at the end of experiment by using 3 males per each treatment where, the birds were individually housed in metabolic cages (60 $\mathrm{cm}$ long. $50 \mathrm{~cm}$ wide. $60 \mathrm{~cm}$ high) and fed their respective experimental diets (Table 2) .The excreta were collected, dried in a forced oven at $65{ }^{\circ} \mathrm{C}$ for 48 hours, ground well and stored to analysis. The proximate analysis of experimental diet and the excreta were carried out according to the official methods (A.O.A.C., 1990). The procedure described by Jakobsen et al. (1960) was used for separating fecal protein in excreta samples. The method depends on the controlled oxidation of uric acid to allantoin by potassium permanganate followed by the precipitation of the protein which represent the undigested crude protein in the excreta. Urinary organic matter was determined according to Abou - Raya and Galal ( 1971 ).

Nitrogen retention (NR) was calculated from the following formula, NR $=(\mathrm{N}$ content of dry matter of dry feed $-\mathrm{N}$ content of dried excreta) $\mathrm{x} 100 / \mathrm{N}$ content of dry feed.

\section{Slaughter test:}

At the end of study, three hens/ treatment were taken and slaughtered. The relative weight of proventriculus, gizzard, abdominal fat and relative length of small intestine and ceca were determined. The weight of proventriculus, gizzard and abdominal fat were expressed relative to their body weight. The lengths of small intestine and ceca were also measured per $100 \mathrm{~g}$ of the body weight. Also, at the time of slaughter, blood samples were collected in clean tubes without anticoagulant, and then the blood was centrifuged at $3500 \mathrm{rpm}$ for 15 minutes to separate the serum that used for determination of total cholesterol, HDL, LDL, triglycerides, AST and ALT enzymes. These biochemical measurements were performed calorimetrically by using commercial kits.

\section{Economical efficiency:}

Economical efficiency for egg production and hatchability were expressed as hen-production and calculated using the following equation:

Economic efficiency $(\%)=($ Net return LE/Total feed cost LE) $\times 100$.

\section{Statistical analysis:}

Data were statistically analyzed using General Linear Models Procedure of the SPSS (2008), differences between treatments were subjected to Duncan' $\mathrm{S}$ Multiple Range - test (Duncan, 1955).

The following model was used to study the effect of treatments on the parameters investigated as follows:

$\mathrm{Yij}=\mu+\mathrm{Ti}+$ eij where:

Yij $=$ an observation,

$\mu=$ overall mean,

$\mathrm{Ti}=$ effect of treatment $(\mathrm{i}=1,2,3,4,5,6)$

eij $=$ Random error .

\section{RESULTS AND DISCUSSION}

\section{Body weight:}

Results in Table (3) showed that the birds fed diet contained $4.42 \% \mathrm{CF}$ (4\% OK), $4.45 \% \mathrm{CF}$ (7\% SFM) and $5.6 \% \mathrm{CF}(7 \%$ $\mathrm{SFM}+4 \% \mathrm{OK})$ recorded the heaviest $\mathrm{BW}$ compared to the control diet $(3.2 \% \mathrm{CF})$ which always had the lowest significantly BW and CBW comparing with the other treatments except for the diet contained $5.42 \% \mathrm{CF}(8 \% \mathrm{OK})$. These results are consist with a previous report regarding the growth performance of pullets fed diets 
containing 0,3 , and $6 \%$ whole rice hull as a source of insoluble fiber, where final BW and $\mathrm{BW}$ change were higher by increasing the dietary crude fiber than control (Incharoen and Maneechore 2013). The increment in change BW may be attributed to insoluble fiber can affect the gut transit time of digest which may improve the ability of endogenous enzymes to successful access to their related substrates (Choct et al., 2010). Also, a significant relationship was observed between the water-soluble xylose content of the soybean meals and the improvements in weight gain obtained when sunflower meal replaced some of the soybean meal (Choct et al., 2010). However, it is evident that the experiments were carried out on adult hens (24 weeks of age) that had already reached the average of mature live body weight of this strain. Physiologically somewhat the increase above this average record indicates that hens tended to obesity and reflects the incidence of abdominal and visceral fat deposition, a matter which is considered a disadvantage especially with egg laying hens.

\section{Egg production and Egg mass:}

Results concerning the effect of dietary different levels of crude fiber on laying performance of Sinai laying hens are presented in Table 4. Under condition of the current study, after 4 weeks of consuming the experimental diets it is clearly from the results that egg number / hen or laying rate \% were significantly higher in hens fed the control diet $(3.2 \%$ $\mathrm{CF})$ than those fed the diets contained higher levels of crude fiber. In addition, results of egg number / hen during the collective period (24-40 weeks of age) showed the same trend observed during the first period. Egg weight during the periods 24-28 and 28-32 weeks of age indicated that all treatments did not differ from control diet, but during the overall period from 24-40 weeks of age all different levels of crude fiber showed higher egg weight values than control diet $(3.2 \% \mathrm{CF})$ with exception the eggs produced by hens fed diet contained $5.42 \% \mathrm{CF}(8 \% \mathrm{OK})$ where it did not significantly differ from control diet. Egg mass are closely related to egg number records which indicate that the control diet $(3.2 \% \mathrm{CF})$ produced significantly greater egg mass than those fed diets containing higher fiber levels except for the diet with $5.6 \% \mathrm{CF}(7 \%$ SFM and $4 \% \mathrm{OK}$ ).

\section{Feed intake and feed conversion ratio:}

Dietary of different levels of crude fiber did not appear to influence on feed intake during the periods 24-28 weeks of age compared to the control diet $(3.2 \% \mathrm{CF})$ as shown in Table (5). On the other hand, feed intake of the hens fed diets contained 4.42 $\%$ and $5.6 \% \mathrm{CF}$ (4\% OK and $7 \%$ SFM+4\%OK) were significantly increased as compared to the control diet during 3236 weeks of age. Also, feed consumption significantly increased with diet containing $5.6 \% \mathrm{CF}(7 \% \mathrm{SFM}+4 \% \mathrm{OK})$ as compared to control diet, while the other treatments had no significant influence on feed intake during the period 36-40 weeks of age and the same trend was showed during the collective period. Results given in Table (5) represented the feed conversion ratio in response to feeding different levels of dietary CF. In comparison with the control diet, it is noticed that all the birds fed diets different levels of CF recorded significantly the least values except for the diet with $5.66 \% \mathrm{CF}(14 \% \mathrm{SFM})$ after 4 weeks of consuming the experimental diets,. Both diets contained 4.42 and $5.42 \%$ CF (4\% and $8 \% \mathrm{OK}$ ) resulted in a significant increase in feed conversion comparing with control during 32-36 weeks of age. The superiority of control diet $(3.2 \% \mathrm{CF})$ with respect to feed conversion ratio was sustained during the whole experimental period.

\section{Egg quality:}

Results of Table (6) showed insignificant differences in all egg quality traits except for yolk index and haugh units due the feeding different levels of dietary $\mathrm{CF}$, 
where all treatments caused significantly decreased in yolk index with exception the diet contained $4.42 \% \mathrm{CF}(4 \% \mathrm{OK})$ compared to the control diet. On the other hand, in comparison with the control diet, it is clear that all experimental diets resulted in a significantly increased in haugh units except the hens fed diet contained $4.45 \%$ CF (7\% SFM) which did not significantly differ from control value for this trait.

Results of the current study indicated that diets contained 4.45, 5.66 and $5.6 \%$ CF (7, $14 \%$ SFM and $7 \%$ SFM+4\%OK) did not have a harmful impact on the productive performance of Sinai laying hens during the period 24-40 weeks of age. These results are in the line with the findings of Roberts et al., (2007) who found that inclusion of moderate amounts of different fiber sources such as soybean hulls had no adverse effects on egg production and egg quality. Also, Casartelli et al., (2006) suggest that layers appear to tolerate the higher levels of SFM, despite its higher crude fiber content, with no decrease in egg production performance or egg quality parameters. Rezael and Hafezian (2007) concluded that soybean and SFM are used nearly in equal amount in layer diets (10\%), without adverse effect on performance which can be explained by fact that layers have a more developed digestive system in respect of gut capacity as compared to pullets and broilers. Beside, unlike most other oilseed meals, SFM does not contain high concentrations of antinutritive factors. Additionally, Kalmendalet al. (2011) reported that the inclusion in the diet of high levels of sunflower meal, an insoluble source of dietary fiber, was associated with significant decreases in colony counts of Clostridium spp. However, Reports on the use of SFM in poultry diets are not always consistent, probably due to differences chemical composition of SFM, processing method, bird age, and food formulation techniques used in the various studies. For example, Serman et al. (1997), evaluating the effect of decorticated SFM as protein source in commercial layer diets on production performance, who concluded that diets formulated with this ingredient needed to be supplemented with lysine. On the other hand, according to the study by Victor et al. (2013) who reported that the percent hen-day egg production and feed conversion ratio were significantly better for layers fed diet contained with insoluble fiber.

In reality, it is probable that the level and type of dietary fiber (DF), as well as the age of the bird, modify the response of laying hens with respect to productive performance. Thus, it could be mentioned that the poor productive performance obtained when the tow levels of CF (4.42 and $5.42 \%$ ) from inclusion 4 and $8 \%$ OK without SFM is speculative, it may be attributed to some reasons 1-the high lignin content in the OK where, the lignin was found to be $8.74 \%$ in SFM while it was 13.8\% OK (Table 1). According to Amici et al. (1991) the lignin limits the feed value of $\mathrm{OK}$, also, crude protein is rather low and it is worth noticing that and most crude protein is linked to acid detergent fiber (Alvarez-Rodriguez et al., 2009). 2-Also, this effect perhaps due to the high level of soluble non-starch polysaccharides (soluble-NSPs) in OK, where soluble NSPs increase viscosity (Smith and Annison 1996) and usually have anti-nutritive properties. Soluble NSPs generally hamper the digestion process (Leeson and summers 2001) whereas insoluble NSPs impede the access of endogenous enzymes to their substrates by physical entrap (Dänicke et al., 1999). However, it is remarkable that when the low levels of SFM and OK were added together $(7 \%$ $\mathrm{SFM}+4 \% \mathrm{OK}$ ) the laying performance (egg mass) significantly increased by about $9.8 \%$ from diet with $4 \%$ OK $(4.42 \% \mathrm{CF})$ alone suggesting a synergistic effect. The likely reason for this effect due to the ratio between the insoluble and soluble fiber in the diet, where this ratio appears to be 
important in the diets formation to provide optimal efficiency (Burhalter et al., 2001). Therefore, the beneficial effects of fiber inclusion on the laying performance were related to improved nutrient digestibility (Table 8) rather than to changes in the metabolic pathways. In addition, the effects of dietary fiber on productivity differ depending on the solubility of the fiber source and its other physicochemical properties, structural components of the diets, such as the insoluble dietary fiber fraction, improve gizzard function, which, in turn, positively affects gut physiology and bird productivity. Thus, the amount of dietary fiber required depends on the characteristics of the fiber source, especially its solubility, lignin content, and particle size.

In terms of feed intake, an excess of feed intake, as occurs in some treatments especially the hens fed diet with 4.42 and $5.42 \% \mathrm{CF}$ (4and $8 \% \mathrm{OK}$ ), usually results in poorer feed conversion ratio than expected, but the inclusion of an adequate amount of dietary fiber might avoid an excessive feed intake in laying hens, resulting generally in better productivity. As a rule ,the results in the present study indicated that the effects of dietary fiber on voluntary feed intake, gastrointestinal tract motility , enzyme production and consequently on the productive performance will differ depending on the level and source of fiber where Miller Jones (2004) and Montagne et al. (2003) reported that differences in the structure and properties of the existing fiber sources affect the rate of passage in different ways, and affect digesta $\mathrm{pH}$ and volatile fatty acid production in the different segments of the gastrointestinal tract.

\section{Fertility and hatchability:}

Results in Table (7) clearly showed that fertility $\%$ of eggs from hens fed diet contained $\quad 4.45 \% \quad \mathrm{CF}(7 \% \quad \mathrm{SFM})$ was insignificantly higher than control diet by about $1.32 \%$, but this improvement was significantly as compared to the other experimental groups. In this respect, the two high levels of CF (5.66 and 5.42\%) as a result the diets contained 14\% SFM and $8 \%$ OK resulted in a significant decrease comparing with control diet, but the diet contained $5.6 \% \mathrm{CF}(7 \% \mathrm{SFM}+4 \% \mathrm{OK})$ ameliorated the adverse effect of diets contained 5.66 and $5.42 \%$ CF (14\% SFM and $8 \% \mathrm{OK}$ ). It is worth to mention that the moderate level of $\mathrm{CF}(4.45 \%)$ resulted from inclusion $7 \%$ SFM resulted in a significant higher hatchability of set eggs than control and other treatments. In addition, the hatchability of fertile eggs tends to significantly increase in diets with 4.45, 4.42 and $5.6 \%$ CF (7\% SFM, 4\% OK and $7 \% \mathrm{SFM}+4 \% \mathrm{OK}$ ) as compared to the control diet. The same manner, results of embryonic mortality come in accordance with those of scientific hatchability, thus the results illustrated that the greater total of embryonic mortality occurred in control diet where it was $8.33 \%$ followed by the diets with $5.66 \%$ CF $(14 \%$ SFM) and $5.42 \% \mathrm{CF} \quad(8 \% \quad \mathrm{OK})$ which were insignificantly differ from the control diet, but embryonic mortality significantly improved by the diets contained 4.45, 4.42 and $5.6 \% \mathrm{CF}$ (7\% SFM, 4\% OK and $7 \% \mathrm{SFM}+4 \% \mathrm{OK})$ compared to control group meanwhile the other treatment did not actually differ from control diet in this trait. Also, chick weight at hatch significantly increased by the diets contained a moderate amount of a CF (4.45 and $4.42 \%$ ) and the diet with $5.6 \% \mathrm{CF}$ $(7 \% \mathrm{SFM}+4 \% \mathrm{OK})$ comparing with control diet.

Little information is available regarding the effect of different levels of dietary crude fiber on reproductive performance of broiler breeder hens. In the current experiment, the diet with $4.54 \% \mathrm{CF}(7 \%$ SFM) had increased fertility and significantly improved all parameters of reproductive performance compared to control diet. In addition, the diets contained $4.42 \% \mathrm{CF}(4 \% \mathrm{OK})$ and $5.6 \% \mathrm{CF}(7 \%$ 
SFM+4\%OK) resulted in a significant improve in hatchability of fertile eggs, embryonic mortality and chick weight at hatch comparing with the control diet $(3.2 \% \quad \mathrm{CF})$. These results suggest a synergistic effect between the low levels of SFM and OK, in addition it illustrated that the inclusion in the diet of moderate amounts of $\mathrm{CF}$ improves the reproductive traits, but the poor reproductive performance obtained when high levels of $\mathrm{CF}$ were used. Recent scientific publications stated that an appropriate level of crude fiber is recommended practices to improve reproductive performance of broiler breeder hens (Mohiti-Asli et al., 2012). Also, addition of alfalfa meal as a source of insoluble fiber to quail breeder diets slightly increased hatchability of fertile eggs (Olgun and Yildiz 2015). This may be attributes to difference work mechanisms of SFM and OK, initially perhaps in contrast to soybean meal, SFM contains lower quantities of antinutritional compounds (Canibe et al., 1999). On the basis of the results by Mateos et al. ( 2012 ) who suggested that laying hens fed highprotein corn-soybean meal diets will benefit from inclusion in the diet of 2 to $3 \%$ oat hulls or another source of insoluble dietary fiber. In respect of $\mathrm{OK}$, this improvement in reproductive traits probably due to the olive oil in OK where OK contain $18.92 \%$ fat (Table 1). Mailer (2006) reported that olive oil contains tocopherols, fatty alcohols, waxes and hydrocarbons, such as squalene pigments (chlorophyll and carotenoids) and $\beta$ carotene which acts as an antioxidant. Servili et al. (2014) illustrated that the nutritional value of olive oil is due to the high monounsaturated fatty acid content, principally made of oleic acid. Hydrophilic and lipophilic phenols represented the main antioxidants of olive oil and they include a large variety of compounds. Thus, these data can be explained by the fact that chick embryo development is associated with an accumulation of polyunsaturated fatty acids in tissue lipids (Speake et al., 1998) making them susceptible to lipid peroxidation (Surai, 1999a). Antioxidant compounds deposited into yolk (Krause and Ternes, 1999) making them less susceptible to lipid peroxidation and consequently increase the adaptation mechanism to deal with overproduction of free radicals and increased the hatchability. In addition, the improvement in hatchability by the diets with $4.45 \% \mathrm{CF}$ (7\% SFM), $4.42 \%(4 \% \mathrm{OK})$ and $5.6 \% \mathrm{CF}$ $(7 \% \mathrm{SFM}+4 \% \mathrm{OK})$ can be explained as a result of increasing the ratio $\mathrm{HDL} / \mathrm{LDL}$ and decreasing the triglycerides $(\mathrm{mg} / \mathrm{dl})$ in blood serum especially the diet contained $5.6 \% \mathrm{CF} \quad(7 \% \mathrm{SFM}+4 \% \mathrm{OK})$ where this decreasing was about $12.96 \%$ as compared to the control diet as shown in Table (10) and consequently decreased the source of free radicals.

\section{Nutrients digestibility and nitrogen retention:}

The effect of dietary different levels of $\mathrm{CF}$ on nutrients digestibility and nitrogen retention is presented in Table (8). It is evident that the diet contained different levels of CF had no significant influence on dry matter $(\mathrm{DM})$, organic matter $(\mathrm{OM})$, and nitrogen free extract (NFE) digestibility. On the other hand the results showed that the best values of $\mathrm{CP}$ digestibility were observed by the diets contained 4.54, 5.42 and $5.6 \% \mathrm{CF}$ (7\% SFM, 8\% OM and $7 \%$ SFM+8\%OK) which were significantly higher than control .Also, in terms of ether extract (EE), all different levels of $\mathrm{CF}$ resulted in a significantly higher $\mathrm{EE}$ digestibility than control diet $(3.2 \% \mathrm{CF})$. In addition, the results illustrated that all dietary levels of CF significantly exceeded the digestibility of crude fiber comparing with the control diet except for the diet with $4.42 \% \mathrm{CF}$ (4\% OK) which produced insignificantly higher digestibility of crude fiber than control.

Similar results on the effects of dietary fiber (DF) on starch digestibility have been reported by others (Hetland et al., 2003 
and Svihus, et al., 2004) in broilers and in laying hens. Also, These results are consist with Kalmendal et al. (2011)who reported that the inclusion of high fiber sunflower meal up to $30 \%$ in a pelleted corn basal diet resulted in significant linear increases in digestibility of fat. In addition, Abdallah et al. (2015) reported that ether extract (EE) digestibility was significantly greater for the all higher levels of dietary crude fiber especially for the diets contained 4.77, 6.23 and $6.2 \% \mathrm{CF}(5 \% \mathrm{OK}, 10 \% \mathrm{OK}$ and $7 \%$ $\mathrm{SFM}+5 \% \mathrm{OK})$ as compared to the control diet $(3.65 \% \mathrm{CF})$, also, in respect of digestibility of crude fiber all dietary different levels of fiber significantly exceeded the digestibility of crude fiber as comparing with the control diet, but the best value was observed with $5.9 \% \mathrm{CF}$ (14\% SFM) except for the diet with $4.2 \mathrm{CF}$ ( $4 ? \%$ OK). The likely reasons for this improvement in nutrients digestibility results from fed diets containing moderate amounts of crude fiber are more elusive, it could be explained as follow: 1--Insoluble dietary fiber has a more abrasive action, scraping mucin from the mucosa as it passes along the gastrointestinal tract (Montagne et al.,2003) and increasing endogenous losses. 2- The increase in dietary fiber (in both the soluble and insoluble fractions of the hays) may have triggered an increase in the physical and chemical activities of the small intestine, causing adaptive hyperplasia to the intestinal mucosa, with consequent increase in intestinal volume in an attempt to improve digestive capacity, also the insoluble fiber decreases the nutrient concentration may also play a role by increasing digestive juices (Hetland et al., 2005). 3- According to Jiménez-Moreno et al. (2009) the insoluble fiber increases grinding activity of the gizzard together with a better mixing of digestive juices with the digesta attributable to the increase in antiperistaltic movements within the gastrointestinal tract, this effect might explain the positive effects of insoluble dietary fiber on the digestibility of dietary components.4- Insoluble fiber enhances proper development of intestinal villi which is necessary for efficient nutrient absorption (Sarikhan et al., 2010). 5- The inclusion of an insoluble fiber source, in the diet, improved gizzard functionality and might mechanically activate the mucosal surface, increasing GIT motility and reducing the chances of bacteria, adhering to the mucosal surface in the distal part of the GIT (Kalmendal et al., 2011). 6- Also, it is probable that the longer retention time and the better gizzard functioning resulting from fiber inclusion stimulated gizzard activity and $\mathrm{HCl}$ secretionin the proventriculus (Mateos et al., 2012).

It is clearly evident that all values of nitrogen intake tend to be significantly increased for birds fed diets with different levels of $\mathrm{CF}$ compared to the control diet. Also, the birds fed diets contained $4.45 \% \mathrm{CF}$ (7\% SFM), 5.66\% (14\%SFM) and $5.6 \% \mathrm{CF}(7 \% \mathrm{SFM}+4 \% \mathrm{OK})$ recorded significantly the highest nitrogen excreta as compared to the control. Generally, results in the current study showed that nitrogen retention was significantly higher in birds fed $5.42 \% \mathrm{CF}(8 \% \mathrm{OK})$ than control by about $8.5 \%$ followed by the diets with 4.45 , $4.42 \% \mathrm{CF}$ (7\%SFM and $4 \%$ OK). Therefore, According to Roberts et al., (2007) increasing the dietary fiber content may be a feasible option to mitigate $\mathrm{NH}_{3}$ emission in a commercial pullets and laying hens.

\section{Relative weight of gizzard and other} segments of gastrointestinal tract (GIT):

The mean values for relative weight of proventriculus, gizzard and abdominal fat as well as the relative length of duodenum, jejunum, illume and ceca are presented in Table (9). No significant influence of different levels of dietary crude fiber during the laying period at 40 weeks of age on the relative weight of sections of GIT and relative length of small intestine. On the other hand, the relative length of ceca was significantly decreased by only the diet 
contained $5.6 \% \mathrm{CF}(7 \% \mathrm{SFM}+4 \% \mathrm{OK})$ as compared to the control diet. Also, these values showed a significantly lower relative weight of abdominal fat by the birds fed diet with $5.42 \% \mathrm{CF}(8 \%$ OK) comparing with the control diet.

These results are in harmony with earlier study by Victor et al. (2013) who mentioned that the different segment of gastrointestinal tract in laying hens was not affected by the dietary inclusion by $0.80 \%$ of insoluble raw fiber concentration. But, contrary to the preset findings, a number of reports indicated increased in weight of the GIT or some of its segments with increased consumption of dietary fiber. It has been demonstrated in laying hens that consumption of $4 \%$ feed as wood shavings resulted in a 50\% heavier gizzard (Hetland et al., 2003). Also, feeding growing pullets (11-19 weeks) with diets containing different levels of $\mathrm{CF}$ resulted in significantly increased in the relative weight of gizzard and relative length of ceca (Abdallah et al., 2015). However, it could be mentioned that the findings in the present study can be explained by fact that layers have a more developed digestive system in respect of gut capacity as compared to pullets and broilers. Thus, it was probable that a moderate amount of $\mathrm{CF}$ elicited beneficial effects to GIT functions but it was likely that these aspects were realized with different levels of $\mathrm{CF}$ inclusion in the diet, without concomitant increase in weight of the GIT. Consequently, CF inclusion is not expected to produce any increase in size of digestive organs in agreement with results reported by Hetland and Svihus (2007) in 35-wkold laying hens.

\section{Biochemical parameters of blood:}

Different dietary of $\mathrm{CF}$ resulted insignificant differences in some serum constituents which included total cholesterol, high density lipoprotein (HDL), low density lipoprotein (LDL) and triglycerides (TG) as shown in Table (10). Although, the different levels of CF did not significant influence on HDL $\%$, hens fed diet with $5.6 \% \mathrm{CF}(7 \% \mathrm{SFM}+4 \% \mathrm{OK})$ tend to have greater HDL \% than control, also, all treatments tend to have higher HDL/LDL than those fed 3.2\% CF (control diet). In addition, Varastegani and Dahlan (2014) showed that additional increase of dietary fiber leads to significant impact on serum indexes including total cholesterol, TG, LDL and HDL. A drawn poultry of lower adipose tissue is the result of high fiber level; perhaps, VLDL is a limiting element for lipid synthesis (Shixia and Na, 2006). Conversely, the hens fed diets contained 4.45, 4.42 and $5.42 \% \mathrm{CF}$ (7\% SFM, $4 \% \mathrm{OK}$ and $8 \% \mathrm{OK}$ ) recorded significantly the lowest values of AST as compared to control diet, while the other treatment recorded nearly the same value of control. In terms of ALT, no significant influence of dietary CF on ALT could be detected, but significant effect was detected among the treatments where, the birds fed diets contained $5.66 \% \mathrm{CF} \quad(14 \% \mathrm{SFM})$ resulted in a significant lower ALT than those fed diets $4.42,5.4$ and $5.42 \% \mathrm{CF}$ (7\% SFM, $8 \% \mathrm{OK}$ and $7 \% \mathrm{SFM}+4 \% \mathrm{OK}$ respectively). In this respect, serum AST activity greater than $230 \mathrm{IU} / \mathrm{L}$ are considers abnormal (Calbreath 1992). Other believe that ALT is not a useful diagnostic test for liver disease in birds (Lumeij et al., 1997). Thus, the increases in ALT and AST could not considered evidence for the presence of any serious damages to the liver.

\section{Economic efficiency (EE) of egg production:}

Results concerning the EE of egg production as influenced by different levels of CF are presented in Table (11). The results indicated that no significant effect on $\mathrm{EE}$ of egg production due to the diet contained $5.66 \% \mathrm{CF}$ (14\%SFM) compared to the control diet followed by the diet with $5.6 \% \mathrm{CF}(7 \% \mathrm{SFM}+4 \% \mathrm{OK})$ where as for the diet contained 5.6 CF did not significantly differ from the diet with $5.6 \mathrm{CF}$. In addition, no significant differences in EEf 
of egg production could be detected among the diets contained $5.6 \%(7 \% \mathrm{SFM}+4 \%$ $\mathrm{OK}), 5.42 \% \quad(8 \% \mathrm{OK})$ and $4.45 \% \quad \mathrm{CF}$ (7\%SFM). On the other hand, the hens fed diet with $4.42 \% \mathrm{CF}(4 \% \mathrm{OK})$ produced the lowest value of EE of egg production than achieved by the control and other diets.

\section{Economic efficiency of hatchability:}

As shown in Table (12), from the records of EE of commercial hatchability it could be concluded that all different levels of $\mathrm{CF}$ caused insignificant influence on $\mathrm{EE}$ of hatchability as compared to the control diet except for the birds fed diet with $4.42 \% \mathrm{CF}$ $(4 \% \mathrm{OK})$ where this diet resulted in a significant lower EE of hatchability then control.

\section{Conclusion:}

These results demonstrated that a positive correlation between a moderate amounts of $\mathrm{CF}$ in the diets of laying hens and nutrient digestibility resulting in enhance birds welfare without any detrimental effects on egg weight, egg mass, egg quality and $\mathrm{EE}$ of egg production in respect of the diets contained $5.66 \% \mathrm{CF} \quad(14 \% \mathrm{SFM})$ and $5.6 \% \mathrm{CF}(7 \% \mathrm{SFM}+4 \% \mathrm{OK})$. In addition, the results illustrated that different levels of $\mathrm{CF}$ in this study can be used to enhance hatchability, EM and chick weight at hatch without any harmful impact on EEf of hatchability except for the diet with $4.42 \% \mathrm{CF}(4 \% \mathrm{Ok})$.

Table (1): Chemical composition and metabolizable energy (ME) content of high fiber Sunflower meal (SFM) and Olive cake (OK) in Egypt

\begin{tabular}{|l|c|c|}
\hline \multirow{2}{*}{ Nutrients (\%) } & \multicolumn{2}{|c|}{ As fed basis } \\
\cline { 2 - 3 } & SFM & OK \\
\hline Moisture & 8.43 & 6.16 \\
Dry Mater & 91.57 & 93.84 \\
Crude Protein & 32.65 & 6.79 \\
Crude Fat & 1.26 & 18.92 \\
Crude Fiber & 25.22 & 33.32 \\
Neutral detergent fiber (NDF) & 35.23 & 57.00 \\
Acid detergent fiber (ADF) & 29.8 & 41.65 \\
Cellulose & 21.05 & 27.85 \\
Hemicellulose & 5.43 & 15.35 \\
Lignin & 8.74 & 13.80 \\
Ash & 6.09 & 10.92 \\
NFE & 16.34 & 0.21 \\
ME (kcal/kg) * & 1619 & 1728 \\
\hline
\end{tabular}

* Metabolizable Energy (ME, kcal/kg) was calculated according to NRC (1994) where $\mathrm{ME}=36.63 \times \mathrm{CP}+77.97 \times \mathrm{EE}+19.87 \times \mathrm{NFE}$. 
Table (2): Composition and calculated analysis of the experimental diets (24-40 weeks of age).

\begin{tabular}{|c|c|c|c|c|c|c|}
\hline \multirow{3}{*}{ Ingredients $(\%)$ Diets } & \multicolumn{6}{|c|}{ Dietary fiber level, \% } \\
\hline & 3.20 & 4.45 & 5.66 & 4.42 & 5.42 & 5.60 \\
\hline & $\begin{array}{c}1 \\
\text { (control) }\end{array}$ & 2 & 3 & 4 & 5 & 6 \\
\hline Yellow corn & 68 & 65.5 & 63 & 63 & 60.3 & 61.5 \\
\hline Soy bean meal (44 \%) & 22.45 & 15.5 & 8 & 22.45 & 17.65 & 14 \\
\hline Corn gluten $(60 \%)$ & - & 1.45 & 3.45 & - & 3.5 & 2.45 \\
\hline Soybean oil & - & 1 & 2 & 1 & 1 & 1.5 \\
\hline Olive cake $(6.79 \%)$ & - & - & - & 4 & 8 & 4 \\
\hline Sunflower meal (32.65\%) & - & 7 & 14 & - & - & 7 \\
\hline Di-calcium phosphate & 1.5 & 1.5 & 1.5 & 1.5 & 1.5 & 1.5 \\
\hline Limestone & 7.4 & 7.4 & 7.4 & 7.4 & 7.4 & 7.4 \\
\hline Vit \& Min. premix ${ }^{1}$ & 0.3 & 0.3 & 0.3 & 0.3 & 0.3 & 0.3 \\
\hline $\mathrm{NaCl}$ & 0.3 & 0.3 & 0.3 & 0.3 & 0.3 & 0.3 \\
\hline DL- Methionine (99\%) & 0.05 & 0.05 & 0.05 & 0.05 & 0.05 & 0.05 \\
\hline Total & 100 & 100 & 100 & 100 & 100 & 100 \\
\hline Calculated Analysis 2 & & & & & & \\
\hline Crude protein $\%$ & 15.14 & 15.08 & 15.19 & 15.03 & 15.05 & 15.00 \\
\hline ME ( Kcal / kg ) & 2781 & 2792 & 1812 & 2766 & 2765 & 1733 \\
\hline Crude fiber $\%$ & 3.2 & 4.45 & 5.66 & 4.42 & 5.42 & 5.6 \\
\hline Calcium (\%) & 3.2 & 3.16 & 3.14 & 3.18 & 3.16 & 3.15 \\
\hline Av. Phosphorus (\%) & 0.398 & 0.378 & 0.36 & 0.39 & 0.38 & 0.37 \\
\hline Methionine \% & 0.33 & 0.304 & 0.285 & 0.32 & 0.34 & 0.30 \\
\hline Methio + Cyst \% & 0.587 & 0.525 & 0.472 & 0.569 & 0.594 & 0.519 \\
\hline Price $(\mathrm{LE} / \mathrm{kg})^{3}$ & 283.42 & 280.32 & 278.02 & 284.27 & 279.85 & $\mathbf{2 7 7 . 8 7}$ \\
\hline
\end{tabular}

1- Each $3 \mathrm{~kg}$ of Vit and Min. premix contains 100 million IUVit A;2 million IU Vit.D $; 10 \mathrm{~g}$ Vit.E; $1 \mathrm{~g}$ Vit. $K_{3} ; 1 \mathrm{~g}$ Vit $\mathrm{B}_{1} ; 5 \mathrm{~g}$ Vit $\mathrm{B}_{2} ; 10 \mathrm{mg}$ Vit. $\mathrm{B}_{12} ; 1.5 \mathrm{~g}$ Vit $\mathrm{B}_{6} ; 30 \mathrm{~g}$ Niacin $; 10 \mathrm{~g}$ Pantothenic acid ; $1 \mathrm{~g}$ Folic acid;50 mg Biotin ; $300 \mathrm{~g}$ Choline chloride; $50 \mathrm{~g}$ Zinc; $4 \mathrm{~g}$ Copper; $0.3 \mathrm{~g}$ Iodine ; $30 \mathrm{~g}$ Iron; $0.1 \mathrm{~g}$ Selenium; 60g Manganese ;0.1 g Cobalt; and carrier $\mathrm{CaCO} 3$ to $3000 \mathrm{~g}$.

2- According to Feed Composition Tables for animal and poultry feedstuffs used in Egypt (2001).

3- Price of one $\mathrm{kg}(\mathrm{LE})$ at time of experiment for different ingredients : yellow corn, 2.27; Soy been meal, 5.05; Corn gluten, 6.50; Wheat bran, 2.22; Olive cake, 0.80; Sunflower meal, 2.75; Di-calcium, 4.55; limestone, 1.50; Vit. \& Min., 20.0; Na cl, 0.50 and Meth, 32.0 
Table (3): Effect of feeding different levels of dietary crude fiber during laying period on growth performance of local Sinai hens

\begin{tabular}{|c|c|c|c|c|c|c|c|c|}
\hline \multirow{2}{*}{$\begin{array}{c}\text { Age } \\
\text { (wks) }\end{array}$} & \multicolumn{6}{|c|}{ Dietary fiber level, \% } & \multirow{2}{*}{$\begin{array}{c}\text { Pooled } \\
\text { SEM }\end{array}$} & \multirow{2}{*}{ Sig. } \\
\hline & $3.2^{1}$ & $4.45^{2}$ & $5.66^{3}$ & $4.42^{4}$ & $5.42^{5}$ & $5.6^{6}$ & & \\
\hline \multicolumn{9}{|c|}{ Body weight (BW) (g/ hen) } \\
\hline Initial(25 & 1278.3 & 1275.0 & 1275.0 & 1280.0 & 1273.3 & 1270.0 & 2.67 & NS \\
\hline $\begin{array}{l}\text { Final } \\
(40 w k s)\end{array}$ & $1620.0^{c}$ & $1740.0^{\mathrm{a}}$ & $1680.0^{\mathrm{b}}$ & $1770.0^{\mathrm{a}}$ & $1658.3^{\mathrm{bc}}$ & $1736.7^{\mathrm{a}}$ & 13.63 & 0.05 \\
\hline $\begin{array}{l}\text { Chang } \\
\text { (CBW) }\end{array}$ & $341.7^{\mathrm{c}}$ & $465.0^{\mathrm{a}}$ & $405.0^{\mathrm{b}}$ & $490.0^{\mathrm{a}}$ & $385.0^{\mathrm{bc}}$ & $466.7^{\mathrm{a}}$ & 13.64 & 0.05 \\
\hline
\end{tabular}

1 control diet (3.2\% CF); 2 Diet with $4.45 \%$ CF (7\% SFM); 3 Diet with $5.66 \%$ CF(14\% SFM); 4Diet with $4.42 \% \mathrm{CF}$ (4\% OK) 5Diet with $5.42 \% \mathrm{CF}(8 \% \mathrm{OK})$; 6Diet with $5.6 \% \mathrm{CF}$ (7\% $\mathrm{SFM}+4 \% \mathrm{OK})$.

a,b,c :means in the same row bearing different superscripts are significantly different $(\mathrm{P} \leq 0.05)$. $\mathrm{NS}=$ non-significant 
Dietary fiber, Sunflower meal, Olive cake and Laying performance Fertility.

Table (4): Effect of feeding different levels of dietary crude fiber on laying performance of local Sinai hens during the laying period from 24 to 40 wks of age

\begin{tabular}{|c|c|c|c|c|c|c|c|c|}
\hline \multirow{2}{*}{$\begin{array}{c}\text { Age } \\
\text { (wks.) }\end{array}$} & \multicolumn{6}{|c|}{ Dietary fiber level, \% } & \multirow{2}{*}{$\begin{array}{c}\text { Pooled } \\
\text { SEM }\end{array}$} & \multirow{2}{*}{ Sig. } \\
\hline & 3.2 & 4.45 & 5.66 & 4.42 & 5.42 & 5.6 & & \\
\hline \multicolumn{9}{|c|}{ Egg number/ hen } \\
\hline $24-28$ & $17.77^{\mathrm{a}}$ & $14.03^{\mathrm{d}}$ & $16.17^{\mathrm{b}}$ & $13.4^{\mathrm{d}}$ & $14.50^{\mathrm{c}}$ & $15.57^{\mathrm{bc}}$ & 0.35 & 0.05 \\
\hline 28-32 & $21.77^{\mathrm{a}}$ & $20.87^{\mathrm{c}}$ & $21.07^{b c}$ & $18.90^{\mathrm{d}}$ & $20.50^{\mathrm{c}}$ & $22.07^{\mathrm{ab}}$ & 0.26 & 0.05 \\
\hline $32-36$ & $21.27^{\mathrm{a}}$ & $20.40^{\mathrm{ab}}$ & $20.70^{\mathrm{a}}$ & $19.67^{b}$ & $20.47^{\mathrm{ab}}$ & $20.87^{\mathrm{a}}$ & 0.15 & 0.05 \\
\hline $36-40$ & $21.50 \mathrm{a}$ & $20.30^{\mathrm{b}}$ & $20.13^{b c}$ & $18.97^{\mathrm{d}}$ & $19.53^{\mathrm{cd}}$ & $20.63^{b}$ & 0.21 & 0.05 \\
\hline $24-40$ & $82.30^{\mathrm{a}}$ & $75.60^{c}$ & $78.07^{\mathrm{b}}$ & $70.93^{\mathrm{d}}$ & $75.47^{\mathrm{c}}$ & $79.13^{\mathrm{b}}$ & 0.88 & 0.05 \\
\hline \multicolumn{9}{|c|}{ Laying rate, \% } \\
\hline $24-28$ & $63.45^{\mathrm{a}}$ & $50.12^{\mathrm{d}}$ & $57.74^{\mathrm{b}}$ & $47.87^{\mathrm{d}}$ & $53.45^{\mathrm{c}}$ & $55.60^{\mathrm{bc}}$ & 1.27 & 0.05 \\
\hline $28-23$ & $77.74 \mathrm{a}$ & $74.52^{\mathrm{c}}$ & $75.24^{\mathrm{bc}}$ & $67.50^{\mathrm{d}}$ & $73.22^{\mathrm{c}}$ & $78.81^{\mathrm{ab}}$ & 0.93 & 0.05 \\
\hline $32-36$ & $75.95^{\mathrm{a}}$ & $72.86^{\mathrm{ab}}$ & $73.93^{\mathrm{a}}$ & $70.24^{\mathrm{b}}$ & $73.16^{\mathrm{ab}}$ & $74.53^{\mathrm{a}}$ & 0.54 & 0.05 \\
\hline $36-40$ & $76.79 \mathrm{a}$ & $72.50^{\mathrm{b}}$ & $71.90^{\mathrm{bc}}$ & $67.74^{\mathrm{d}}$ & $69.76^{\mathrm{cd}}$ & $73.69^{b}$ & 0.74 & 0.05 \\
\hline $24-40$ & $73.48 \mathrm{a}$ & $67.50^{c}$ & $69.70^{\mathrm{b}}$ & $63.33^{\mathrm{d}}$ & $67.38^{c}$ & $70.65^{b}$ & 0.79 & 0.05 \\
\hline \multicolumn{9}{|c|}{ Egg weight, g } \\
\hline $24-28$ & 39.98 & 41.14 & 40.16 & 39.36 & 39.67 & 40.3 & 0.31 & NS \\
\hline $28-32$ & 43.53 & 44.59 & 44.21 & 44.09 & 43.30 & 43.73 & 0.20 & NS \\
\hline $32-36$ & $46.31 \mathrm{~b}$ & $47.20^{\mathrm{ab}}$ & $46.68^{\mathrm{b}}$ & $48.24^{\mathrm{a}}$ & $46.53^{b}$ & $47.12^{\mathrm{ab}}$ & 0.20 & 0.05 \\
\hline $36-40$ & $48.41^{\mathrm{a}}$ & $49.90^{\mathrm{ab}}$ & $48.91^{\mathrm{a}}$ & $50.70^{\mathrm{a}}$ & $48.68^{\mathrm{a}}$ & $49.62^{\mathrm{ab}}$ & 0.25 & 0.05 \\
\hline $24-40$ & $44.76 \mathrm{c}$ & $46.31^{\mathrm{a}}$ & $45.08^{\mathrm{ab}}$ & $46.11^{\mathrm{ab}}$ & $44.84^{\mathrm{bc}}$ & $45.39^{\mathrm{ab}}$ & 0.20 & 0.05 \\
\hline \multicolumn{9}{|c|}{ Egg mass, g/ hen } \\
\hline $24-28$ & $710.33^{\mathrm{a}}$ & $577.24^{c}$ & $649.79^{b}$ & $527.20^{\mathrm{d}}$ & $593.65^{\mathrm{c}}$ & $619.62^{b c}$ & 14.98 & 0.05 \\
\hline $28-32$ & $947.38^{\mathrm{a}}$ & $930.28^{\mathrm{ab}}$ & $931.53^{\mathrm{ab}}$ & $833.17^{\mathrm{c}}$ & $890.57^{b}$ & $964.97^{\mathrm{a}}$ & 11.43 & 0.05 \\
\hline $32-36$ & $984.69^{\mathrm{a}}$ & $962.89^{\mathrm{ab}}$ & $966.08^{a b}$ & $948.80^{\mathrm{b}}$ & $956.64^{\mathrm{ab}}$ & $983.02^{\mathrm{a}}$ & 4.60 & 0.05 \\
\hline $36-40$ & $1040.77^{\mathrm{a}}$ & $1012.95^{\mathrm{ab}}$ & $984.75 b^{c}$ & $961.86^{c}$ & $951.03^{c}$ & $1024.02^{\mathrm{ab}}$ & 9.34 & 0.05 \\
\hline $24-40$ & $3683.12^{\mathrm{a}}$ & $3500.66^{\mathrm{b}}$ & $3519.48^{b c}$ & $3270.42^{\mathrm{d}}$ & $3384.61^{\mathrm{cd}}$ & $3591.67^{\mathrm{ab}}$ & 35.07 & 0.05 \\
\hline
\end{tabular}

a,b,c,d.. :means in the same row bearing different superscripts are significantly different $(\mathrm{P} \leq 0.05)$ 
Table (5): Effect of feeding different levels of dietary crude fiber during laying period on feed consumption and feed conversion ratio of local Sinai hens

\begin{tabular}{|c|c|c|c|c|c|c|c|c|}
\hline \multirow{2}{*}{$\begin{array}{c}\text { Age } \\
\text { (wks.) }\end{array}$} & \multicolumn{6}{|c|}{ Dietary fiber level, \% } & \multirow{2}{*}{$\begin{array}{c}\text { Pooled } \\
\text { SEM }\end{array}$} & \multirow{2}{*}{ Sig. } \\
\hline & 3.2 & 4.45 & 5.66 & 4.42 & 5.42 & 5.6 & & \\
\hline \multicolumn{9}{|c|}{ Feed consumption, g/ hen/day } \\
\hline $24-28$ & 110.4 & 111.22 & 108.09 & 107.64 & 109.3 & 111.34 & 0.52 & NS \\
\hline $28-32$ & $111.64^{\mathrm{ab}}$ & $116.13^{\mathrm{a}}$ & $115.53^{\mathrm{a}}$ & $108.17^{b}$ & $113.72^{\mathrm{ab}}$ & $112.58^{\mathrm{ab}}$ & 0.89 & 0.05 \\
\hline $32-36$ & $122.69^{c}$ & $123.49^{\mathrm{bc}}$ & $124.89^{\mathrm{abc}}$ & $126.74^{\mathrm{a}}$ & $125.24^{\mathrm{abc}}$ & $125.91^{\mathrm{ab}}$ & 0.46 & 0.05 \\
\hline $36-40$ & $122.71^{b c}$ & $122.89^{\mathrm{bc}}$ & $118.25^{\mathrm{c}}$ & $126.95^{\mathrm{ab}}$ & $124.79^{\mathrm{ab}}$ & $130.05^{\mathrm{a}}$ & 1.07 & 0.05 \\
\hline $24-40$ & $116.86^{\mathrm{b}}$ & $118.43^{\mathrm{ab}}$ & $116.69^{\mathrm{b}}$ & $117.38^{b}$ & $118.26^{\mathrm{ab}}$ & $119.97^{\mathrm{a}}$ & 0.38 & 0.05 \\
\hline \multicolumn{9}{|c|}{ Feed conversion ratio, (g F./ g EM) } \\
\hline $24-28$ & $4.36^{\mathrm{c}}$ & $5.06^{\mathrm{b}}$ & $4.67^{\mathrm{cb}}$ & $5.73^{a}$ & $5.16^{\mathrm{ab}}$ & $5.04^{\mathrm{ab}}$ & 0.12 & 0.05 \\
\hline $28-32$ & $3.30^{\mathrm{bc}}$ & $3.50^{\mathrm{abc}}$ & $3.47^{\mathrm{abc}}$ & $3.64^{\mathrm{a}}$ & $3.58^{\mathrm{ab}}$ & $3.27^{\mathrm{c}}$ & 0.44 & 0.05 \\
\hline $32-36$ & $3.49^{\mathrm{b}}$ & $3.59^{\mathrm{ab}}$ & $3.62^{\mathrm{ab}}$ & $3.74^{\mathrm{a}}$ & $3.68^{\mathrm{a}}$ & $3.59^{\mathrm{ab}}$ & 0.03 & 0.05 \\
\hline $36-40$ & $3.3^{c}$ & $3.40^{\mathrm{bc}}$ & $3.36^{\mathrm{bc}}$ & $3.70^{\mathrm{a}}$ & $3.68^{\mathrm{a}}$ & $3.56^{\mathrm{ab}}$ & 0.04 & 0.05 \\
\hline $24-40$ & $3.56^{\mathrm{d}}$ & $3.79^{b c}$ & $3.72^{c}$ & $4.02^{\mathrm{a}}$ & $3.91^{\mathrm{ab}}$ & $3.77^{b c}$ & 0.04 & 0.05 \\
\hline
\end{tabular}

$\mathrm{a}, \mathrm{b}, \mathrm{c}, \mathrm{d},$. means in the same row bearing different superscripts are significantly different $(\mathrm{P} \leq 0.05)$

Table (6): The effect of feeding different levels of dietary crude fiber during laying period on egg quality parameters of local Sinai hens

\begin{tabular}{|c|c|c|c|c|c|c|c|c|}
\hline \multirow{2}{*}{ Parameters } & \multicolumn{6}{|c|}{ Dietary fiber level, \% } & \multirow{2}{*}{$\begin{array}{c}\text { Pooled } \\
\text { SEM }\end{array}$} & \multirow{2}{*}{ Sig. } \\
\hline & 3.2 & 4.45 & 5.66 & 4.42 & 5.42 & 5.60 & & \\
\hline Shape index & 0.793 & 0.783 & 0.788 & 0.788 & 0.788 & 0.794 & 0.003 & $\mathrm{NS}$ \\
\hline $\begin{array}{l}\text { Shell } \\
\text { weight,\% }\end{array}$ & 11.85 & 11.70 & 11.38 & 11.09 & 11.27 & 11.66 & 0.11 & NS \\
\hline $\begin{array}{l}\text { Yolk } \\
\text { weight,\% }\end{array}$ & 30.52 & 30.66 & 31.10 & 31.04 & 31.00 & 31.13 & 0.23 & NS \\
\hline $\begin{array}{l}\text { Albumin } \\
\text { Wt..\% }\end{array}$ & 57.63 & 57.64 & 57.52 & 57.87 & 57.73 & 57.21 & 0.21 & NS \\
\hline Yolk index & $0.218^{\mathrm{a}}$ & $0.196^{\mathrm{bc}}$ & $0.19^{c}$ & $0.215^{\mathrm{ab}}$ & $0.199^{\mathrm{bc}}$ & $0.199^{b c}$ & 0.003 & 0.05 \\
\hline Shell thick. & 0.337 & 0.340 & 0.330 & 0.307 & 0.317 & 0.337 & 0.004 & NS \\
\hline Haught u. & $88.67^{\mathrm{b}}$ & $95.00^{\mathrm{ab}}$ & $101.33^{\mathrm{a}}$ & $100.0^{\mathrm{a}}$ & $97.33^{\mathrm{a}}$ & $99.00^{\mathrm{a}}$ & 1.29 & 0.05 \\
\hline
\end{tabular}

a,b,c :means in the same row bearing different superscripts are significantly different $(\mathrm{P} \leq 0.05)$.

$\mathrm{NS}=$ non-significant 
Table (7): The effect of feeding different levels of dietary crude fiber during laying period on hatchability traits of local Sinai hens

\begin{tabular}{|c|c|c|c|c|c|c|c|c|}
\hline \multirow{2}{*}{$\begin{array}{c}\text { Parameters, } \\
\%\end{array}$} & \multicolumn{6}{|c|}{ Dietary fiber level, \% } & \multirow{2}{*}{$\begin{array}{l}\text { Pooled } \\
\text { SEM }\end{array}$} & \multirow[b]{2}{*}{ Sig. } \\
\hline & 3.2 & 4.45 & 5.66 & 4.42 & 5.42 & 5.60 & & \\
\hline Fertility, \% & $97.13^{\mathrm{ab}}$ & $98.41^{\mathrm{a}}$ & $93.80^{\mathrm{cd}}$ & $95.33^{\mathrm{bc}}$ & $92.27^{\mathrm{d}}$ & $95.07^{\mathrm{bc}}$ & 0.57 & 0.05 \\
\hline $\begin{array}{l}\text { Hatchability of } \\
\text { set eggs, } \%\end{array}$ & $89.05^{\mathrm{b}}$ & $94.71^{\mathrm{a}}$ & $89.14^{\mathrm{b}}$ & $91.23^{\mathrm{b}}$ & $86.03^{c}$ & $90.15^{\mathrm{b}}$ & 0.71 & 0.05 \\
\hline $\begin{array}{l}\text { Hatchability of } \\
\text { fertile eggs, } \%\end{array}$ & $91.67^{\mathrm{c}}$ & $96.25^{\mathrm{a}}$ & $91.73^{\mathrm{c}}$ & $95.70^{\mathrm{a}}$ & $93.24^{\mathrm{bc}}$ & $94.83^{\mathrm{ab}}$ & 0.47 & 0.05 \\
\hline EEM, \% & $1.47^{\mathrm{a}}$ & $0.00^{\mathrm{b}}$ & $1.66^{\mathrm{a}}$ & $0.51^{\mathrm{b}}$ & $1.69^{\mathrm{a}}$ & $1.56^{\mathrm{a}}$ & 0.18 & 0.05 \\
\hline LEM, \% & $6.86^{\mathrm{a}}$ & $3.58^{\mathrm{c}}$ & $6.64^{\mathrm{ab}}$ & $3.63^{c}$ & $509 b^{c}$ & $3.62^{\mathrm{c}}$ & 0.39 & 0.05 \\
\hline Total EM, \% & $8.33^{\mathrm{a}}$ & $3.58^{\mathrm{c}}$ & $8.31^{\mathrm{a}}$ & $4.14^{\mathrm{c}}$ & $6.78^{\mathrm{ab}}$ & $5.17^{\mathrm{bc}}$ & 0.50 & 0.05 \\
\hline $\begin{array}{l}\text { Chick wt. (g) } \\
\text { at hatch }\end{array}$ & $32.4^{\mathrm{c}}$ & $33.67^{\mathrm{ab}}$ & $32.02^{\mathrm{c}}$ & $33.52^{\mathrm{ab}}$ & $32.78^{\mathrm{bc}}$ & $33.88^{\mathrm{a}}$ & 0.19 & 0.05 \\
\hline
\end{tabular}

EEM\& LEM = early (1-7 days of incubation) and late (8-21 days of incubation) embryonic mortality.

$a, b, c, .$. : means in the same row bearing different superscripts are significantly different $(\mathrm{P} \leq 0.05)$

Table (8): Effect of feeding different levels of dietary crude fiber during laying period on digestibility coefficient of nutrients of local Sinai hens

\begin{tabular}{|c|c|c|c|c|c|c|c|c|}
\hline \multirow[b]{2}{*}{ Parameters } & \multicolumn{6}{|c|}{ Dietary fiber level, \% } & \multirow[b]{2}{*}{ SE } & \multirow[b]{2}{*}{ Sig. } \\
\hline & 3.2 & 4.45 & 5.66 & 4.42 & 5.42 & 5.6 & & \\
\hline \multicolumn{9}{|c|}{ Digestibility coefficient, \% } \\
\hline Dry matter & 69.90 & 72.78 & 70.33 & 70.92 & 72.36 & 72.35 & 0.47 & NS \\
\hline Crude protein & $94.06^{\mathrm{b}}$ & $96.33^{\mathrm{a}}$ & $94.0^{\mathrm{b}}$ & $94.66^{\mathrm{b}}$ & $96.17^{\mathrm{a}}$ & $95.88^{\mathrm{a}}$ & 0.26 & 0.05 \\
\hline Ether extract & $35.15 \mathrm{c}$ & $51.71^{\mathrm{b}}$ & $60.86^{\mathrm{a}}$ & $53.39^{\mathrm{b}}$ & $61.28^{\mathrm{a}}$ & $62.05^{\mathrm{a}}$ & 2.36 & 0.05 \\
\hline Crude fiber & $26.93^{c}$ & $37.35^{\mathrm{b}}$ & $47.96^{\mathrm{a}}$ & $29.88^{c}$ & $43.74^{\mathrm{ab}}$ & $49.75^{\mathrm{a}}$ & 2.22 & 0.05 \\
\hline Organic mat. & 73.61 & 76.28 & 74.77 & 74.90 & 73.42 & 76.16 & 0.60 & NS \\
\hline Nitrogen free & 81.41 & 82.93 & 82.00 & 81.45 & 82.66 & 82.89 & 0.37 & NS \\
\hline Ash R. & $40.87^{\mathrm{ab}}$ & $45.31^{\mathrm{a}}$ & $46.90^{\mathrm{a}}$ & $34.37^{\mathrm{b}}$ & $40.14^{\mathrm{ab}}$ & $40.5^{\mathrm{ab}}$ & 1.30 & 0.05 \\
\hline Nitrogen I. g/d ${ }^{1}$ & $0.96^{c}$ & $2.21^{\mathrm{a}}$ & $1.81^{\mathrm{ab}}$ & $1.63^{b}$ & $1.65^{b}$ & $1.88 \mathrm{ab}$ & 0.11 & 0.05 \\
\hline Nitrogen E.g/d ${ }^{2}$ & $0.37 b$ & $0.76 \mathrm{a}$ & $0.77 \mathrm{a}$ & $0.56 \mathrm{ab}$ & $0.54 \mathrm{ab}$ & $0.72 a$ & 0.04 & 0.05 \\
\hline Nitrogen R. ${ }^{3}$ & $61.97^{\mathrm{bc}}$ & $65.90^{\mathrm{ab}}$ & $57.71^{\mathrm{c}}$ & $65.54^{\mathrm{a}}$ & $67.24^{\mathrm{ab}}$ & $62.03^{\mathrm{bc}}$ & 0.95 & 0.05 \\
\hline
\end{tabular}

${ }^{1}$ Nitrogen I= Nitrogen intake (g/day); 2 Nitrogen $E=$ Nitrogen excreta (g/day); Nitrogen $R=$ Nitrogen retention

$a, b, c, .$. : means in the same row bearing different superscripts are significantly different $(P \leq 0.05)$ 
Table (9): Effect of feeding different levels of dietary crude fiber during laying period on relative weight proventriculus, gizzard, relative length of small intestine and ceca for local Sinai hens at 40 weeks of age

\begin{tabular}{|c|c|c|c|c|c|c|c|c|c|}
\hline \multirow{2}{*}{\multicolumn{2}{|c|}{ Items }} & \multicolumn{6}{|c|}{ Dietary fiber level, \% } & \multirow{2}{*}{$\begin{array}{c}\text { Pool } \\
\text { ed } \\
\text { SE } \\
\text { M }\end{array}$} & \multirow[b]{2}{*}{ Sig. } \\
\hline & & 3.2 & 4.45 & 5.66 & 4.42 & 5.42 & 5.6 & & \\
\hline LBW & (g) & 1828.0 & 1959.7 & 1907.0 & 1960.3 & 1957.7 & 1950.7 & 28.6 & $\mathrm{NS}$ \\
\hline \multicolumn{10}{|c|}{ Parameters, \% } \\
\hline \multicolumn{2}{|c|}{ Carcass } & 62.71 & 63.11 & 65.30 & 64.21 & 64.32 & 63.12 & 1.22 & NS \\
\hline \multicolumn{2}{|c|}{ Provent. } & 0.354 & 0.388 & 0.377 & 0.343 & 0.402 & 0.335 & 0.01 & $\mathrm{NS}$ \\
\hline \multicolumn{2}{|c|}{ Gizzard } & 1.46 & 1.52 & 1.63 & 1.35 & 1.44 & 1.24 & 0.05 & $\mathrm{NS}$ \\
\hline \multirow{5}{*}{ 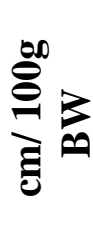 } & Duod. & 2.05 & 1.99 & 1.81 & 1.79 & 1.66 & 1.60 & 0.07 & NS \\
\hline & Jej. & 3.87 & 3.84 & 3.55 & 3.97 & 3.81 & 3.38 & 0.11 & $\mathrm{NS}$ \\
\hline & Ileum & 3.97 & 3.69 & 3.26 & 3.61 & 3.57 & 3.17 & 0.12 & NS \\
\hline & Total & 9.89 & 9.51 & 8.62 & 9.36 & 9.05 & 8.15 & 0.24 & $\mathrm{NS}$ \\
\hline & Ceca & $2.02^{\mathrm{a}}$ & $1.80^{\mathrm{ab}}$ & $2.00^{\mathrm{a}}$ & $2.03^{\mathrm{a}}$ & $2.06^{\mathrm{a}}$ & $1.56^{\mathrm{b}}$ & 0.06 & 0.05 \\
\hline \multicolumn{2}{|c|}{$\begin{array}{l}\text { Abdominal } \\
\text { Fat }\end{array}$} & $4.50^{\mathrm{ab}}$ & $4.73^{\mathrm{ab}}$ & $3.65^{\mathrm{bc}}$ & $4.62^{\mathrm{ab}}$ & $3.08^{c}$ & $5.12^{\mathrm{a}}$ & 0.22 & 0.05 \\
\hline
\end{tabular}

a,b,c :means in the same row bearing different superscripts are significantly different $(\mathrm{P} \leq 0.05)$.

$\mathrm{NS}=$ non-significant

Table (10) Effect of feeding different levels of dietary crude fiber during the laying period on some serum constituents in local Sinai hens

\begin{tabular}{|c|c|c|c|c|c|c|c|c|}
\hline \multirow[b]{2}{*}{ Criteria } & \multicolumn{6}{|c|}{ Dietary fiber level, \% } & \multirow{2}{*}{$\begin{array}{c}\text { Pooled } \\
\text { SEM }\end{array}$} & \multirow[b]{2}{*}{ Sig. } \\
\hline & 3.2 & 4.45 & 5.66 & 4.42 & 5.42 & 5.6 & & \\
\hline $\begin{array}{l}\text { Total cholest. } \\
(\mathrm{mg} / \mathrm{dl})\end{array}$ & 210.80 & 208.92 & 182.63 & 154.93 & 195.78 & 227.70 & 15.39 & NS \\
\hline $\begin{array}{l}\text { HDL cholest. } \\
(\mathrm{mg} / \mathrm{dl})\end{array}$ & 30.83 & 28.23 & 30.02 & 34.88 & 51.92 & 42.99 & 4.46 & NS \\
\hline $\begin{array}{l}\text { LDL cholest. } \\
(\mathrm{mg} / \mathrm{dl})\end{array}$ & 109.59 & 111.55 & 86.70 & 53.18 & 119.70 & 123.26 & 14.25 & NS \\
\hline HDL/T .chol.,\% & 0.155 & 0.162 & 0.162 & 0.213 & 0.305 & 0.185 & 0.02 & NS \\
\hline HDL/LDL, \% & 0.366 & 0.600 & 0.387 & 0.861 & 0.432 & 0.461 & 0.23 & NS \\
\hline $\begin{array}{l}\text { Triglycerides } \\
(\mathrm{mg} / \mathrm{dl})\end{array}$ & 351.89 & 345.71 & 329.55 & 334.36 & 348.45 & 307.22 & 7.77 & NS \\
\hline $\operatorname{AST}(\mathrm{U} / \mathrm{dl})$ & $1.26^{\mathrm{a}}$ & $1.19^{\mathrm{bc}}$ & $1.22^{\mathrm{ab}}$ & $1.18^{\mathrm{bc}}$ & $1.13^{\mathrm{c}}$ & $1.21^{\mathrm{ab}}$ & 0.011 & 0.05 \\
\hline $\operatorname{ALT}(\mathrm{U} / \mathrm{dl})$ & $0.66^{\mathrm{ab}}$ & $0.69^{\mathrm{a}}$ & $0.58^{\mathrm{b}}$ & $0.66^{\mathrm{ab}}$ & $0.69^{\mathrm{a}}$ & $0.70^{\mathrm{a}}$ & 0.013 & 0.05 \\
\hline
\end{tabular}

A,b,c,. :means in the same row bearing different superscripts are significantly different $(\mathrm{P} \leq 0.05)$. $\mathrm{NS}=$ non-significant 
Dietary fiber, Sunflower meal, Olive cake and Laying performance Fertility.

Table (11): The effect of feeding different levels of dietary crude fiber during laying period on economic efficiency of egg production from 24-40 wks of age

\begin{tabular}{|c|c|c|c|c|c|c|c|c|c|c|}
\hline \multicolumn{2}{|c|}{$\begin{array}{c}\text { Items } \\
\text { Treatments }\end{array}$} & $\begin{array}{c}\text { Total feed } \\
\text { consumed/ } \\
\text { hen } \\
(\mathbf{k g})\end{array}$ & $\begin{array}{c}\text { Feed } \\
\text { layer } \\
\text { cost/ } \\
\text { kg } \\
(\text { LE })^{1} \\
\end{array}$ & $\begin{array}{c}\text { Total } \\
\text { feed } \\
\text { consumed } \\
\text { cost/ hen } \\
(\mathrm{LE}) \\
\end{array}$ & $\begin{array}{c}\text { Egg } \\
\text { number/ } \\
\text { hen }\end{array}$ & 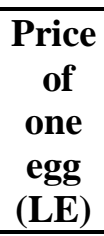 & $\begin{array}{c}\text { Total } \\
\text { return } \\
(\text { LE) }\end{array}$ & $\begin{array}{l}\text { Net } \\
\text { return } \\
(\text { LE) }\end{array}$ & $\begin{array}{l}\text { EEF } \\
(\%)^{2}\end{array}$ & $\begin{array}{c}\text { Relative } \\
\text { EEF }^{3}\end{array}$ \\
\hline \multirow{6}{*}{ 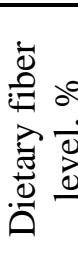 } & 3.2 & 13.9 & 283.42 & 37.10 & 82.30 & 65 & 53.50 & 16.4 & 44.26 & $100 \mathrm{a}$ \\
\hline & 4.45 & 13.26 & 280.32 & 37.25 & 75.60 & 65 & 49.14 & 11.89 & 31.90 & $72.29 \mathrm{c}$ \\
\hline & 5.66 & 13.07 & 278.02 & 36.34 & 78.07 & 65 & 50.75 & 14.41 & 39.65 & $90.02 \mathrm{ab}$ \\
\hline & 4.42 & 13.14 & 284.27 & 37.36 & 70.93 & 65 & 46.11 & 8.75 & 23.42 & $53.67 \mathrm{~d}$ \\
\hline & 5.42 & 13.24 & 279.85 & 37.06 & 75.47 & 65 & 49.06 & 12.00 & 32.37 & $73.80 \mathrm{c}$ \\
\hline & 5.60 & 13.44 & 277.87 & 37.34 & 79.13 & 65 & 51.44 & 14.10 & 37.77 & $85.90 \mathrm{bc}$ \\
\hline \multicolumn{9}{|c|}{ Pooled SEM } & & 3.90 \\
\hline \multicolumn{9}{|l|}{ Sig. } & & 0.05 \\
\hline
\end{tabular}

${ }^{1} \mathrm{LE}=$ Egyptian pound according to price at the experimental time.

${ }^{2} \mathrm{EEF}(\%)=$ economic efficiency $(\%)=($ Net return LE $/$ Total feed cost LE $) \times 100$.

${ }^{3}$ Relative EE= Assuming EEF of the control equals $100 \%$

$\mathrm{A}, \mathrm{b}, \mathrm{c}, . .$. : means in the same column bearing different superscripts are significantly different $\quad(\mathrm{P} \leq$ $0.05)$

Table (12): The effect of feeding different levels of dietary crude fiber during laying period on economic efficiency of hatchability from 20-40 wks of age

\begin{tabular}{|c|c|c|c|c|c|c|c|c|c|c|}
\hline $\begin{array}{r}\text { I } \\
\text { Trea }\end{array}$ & $\begin{array}{l}\text { ms } \\
\text { ments }\end{array}$ & $\begin{array}{c}\text { Total feed } \\
\text { consumed/ } \\
\text { hen } \\
(\mathrm{kg})\end{array}$ & $\begin{array}{c}\text { Feed } \\
\text { layer } \\
\text { cost/ } \\
\text { kg } \\
(\mathrm{LE}){ }^{1}\end{array}$ & $\begin{array}{c}\text { Total } \\
\text { feed } \\
\text { consumed } \\
\text { cost/ hen } \\
\text { (LE) }\end{array}$ & $\begin{array}{c}\text { Egg } \\
\text { number/ } \\
\text { hen }\end{array}$ & $\begin{array}{c}\text { Price } \\
\text { of } \\
\text { Chick } \\
(\text { LE) }\end{array}$ & $\begin{array}{c}\text { Total } \\
\text { return } \\
(\text { LE) }\end{array}$ & $\begin{array}{l}\text { Net } \\
\text { return } \\
(\text { LE) }\end{array}$ & $\begin{array}{l}\text { EEF } \\
(\%)^{2}\end{array}$ & $\begin{array}{c}\text { Relative } \\
\text { EEF }^{3}\end{array}$ \\
\hline & 3.2 & 13.9 & 283.42 & 37.10 & 82.30 & 150 & 113.18 & 76.08 & 205.24 & $100 \mathrm{a}$ \\
\hline$\overline{0}$ & 4.45 & 13.26 & 280.32 & 37.25 & 75.60 & 150 & 109.14 & 71.89 & 192.98 & $94.2 \mathrm{ab}$ \\
\hline & 5.66 & 13.07 & 278.02 & 36.34 & 78.07 & 150 & 107.42 & 71.08 & 195.59 & $95.42 \mathrm{a}$ \\
\hline E9 & 4.42 & 13.14 & 284.27 & 37.36 & 70.93 & 150 & 101.83 & 64.46 & 172.59 & $84.42 b$ \\
\hline$\stackrel{0}{0}$ & 5.42 & 13.24 & 279.85 & 37.06 & 75.47 & 150 & 105.55 & 68.51 & 184.80 & $90.31 \mathrm{ab}$ \\
\hline & 5.60 & 13.44 & 277.87 & 37.34 & 79.13 & 150 & 112.57 & 75.23 & 201.49 & $98.37 \mathrm{a}$ \\
\hline Poole & EM & & & & & & & & & 1.65 \\
\hline Sig. & & & & & & & & & & 0.05 \\
\hline
\end{tabular}

${ }^{1} \mathrm{LE}=$ Egyptian pound according to price at the experimental time.

${ }^{2} \mathrm{EEF}(\%)=$ economic efficiency $(\%)=($ Net return LE $/$ Total feed cost LE $) \times 100$.

${ }^{3}$ Relative EE= Assuming EEF of the control equals $100 \%$

A,b,c,.. : means in the same column bearing different superscripts are significantly different $\quad(\mathrm{P} \leq$ $0.05)$ 


\section{REFERENCES}

Abdallah, A.G.; M.M. Beshara and A.F. Ibrahim (2015). Effect of different levels and sources of dietary fiber on productive and economical performance in local laying hens 1- During growing period and subsequent laying performance. Egypt. Poult. Sci., (35) (I): (367-398)

Abdel Fadeel, N.E. (2006). Nutritional studies on turkey performance using some non-conventional feedstuffs. Ph.D. Thesis, Fac. Of Agric., Cairo Univ.

Abou- Raya, A.K. and A.G.H. Galal (1971). Evaluation of poultry feeds in digestion traits with reference to some factors involved. A.R.E.J Anim. Prod., 11: 207-221.

Afsari, M.; A. Mohebbifar and M. Torki (2014). Effects of dietary inclusion olive pulp supplemented with probiotics on productive performance, egg quality and blood parameters of laying hens. Annual Research \& Review in Biology 4(1):198-211.

Alvarez-Rdriguez, J.; F. Mounz and J. Marrrgatida (2009). Nutritive value of crude and extracted two- stage olive cakes production in Aragon (Spain) Revista elecronica de Veterinaria, 10 (3).

Aerni, V.; H. El-Lethey and B. Wechsler (2000). Effect of foraging material and food form on feather pecking in laying hens. Br. Poult. Sci., 41:16-21.

Amerah, A. M.; V. Ravindran and R. G. Lentle (2009). Influence of insoluble fibre and whole wheat inclusion on the performance, digestive tract development and ileal microbiota profile of broiler chickens. Br. Poult. Sci. 50:366-375.

Amici, A.; M. Verna and F. Martillotti (1991). Olive byproducts in animal feeding: improvement and utilization. Options Méditerranéennes - Series Seminaries, 16: 149-152.
Association of Official Analytical Chemists (AOAC) (1990). Official methods of analysis. $13^{\text {th }}$ Ed. Published by the AOAC., Washington, D.C., USA.

Burhalter, T.M.; N.R. Merchen; L.L. Bauer; S.M. Murray; A.R. Patil; J.L. Brent and G.C. Fahey (2001). The ratio of insoluble to soluble fiber components in soybean hulls affect ileal and total-tract nutrient digestibilities and fecal characteristics of dogs. J. Nutr., 131: 1978-1985.

Calbreath, D.F. (1992). Hepatic enzymes in health and direase. In: Clinical chemistry, A Fun do mental textbook. Eds., Donald F. Calbreath, W.B. Saunders company PP: 182-233.

Canibe, N.; M.M. Pedrosa; L.M. Robredo and K.E.B. Knudsen (1999). Chemical composition, digestibility and protein quality of 12 sunflower (Helianthus Annuus L) cultivars. Journal of the Science of Food and Agriculture, 79: 1775-1782.

Casartelli E.M; R.S. Filardi; O.M. Junqueira; A.C. Laurentiz; V. Assuena and K.F. Duarte (2006). Commercial Laying hens diets formulated according to different recommendations of total and digestible amino acids. Brazilian Journal of Poultry Science., 7(3):177-180.

Choct, M. and D. J. Cadogan (2001). How effective are supplemental enzymes in pig diets? In: Manipulating Pig Production VIII (Ed. P. D. Cranwell. Adelaide, South Australia. pp. 240-247.

Choct, M.; Y. Dersjant-Li; J. McLeish and M. Peisker (2010). Soy oligosaccharides and soluble non-starch polysaccharides: a review of digestion, nutritive and anti-nutritive effects in pigs and poultry. Asian-Aust. J. Anim. Sci., 23, No. 10: 1386 - 1398

Dänicke, S.; G. Dusel; H. Jeroch and H. Kluge (1999). Factors affecting efficiency of NSP-degrading enzymes in rations for pigs and poultry. Aerobiology 
Duncan, D.B. (1955). Multiple ranges and multiple f-test, Biometries 11: 1-42.

El-Hachemi, A.; K.E. El-Mecherfi; K. Benzineb and D. Saidi (2007). Supplementation of olive mill wastes in broiler chicken feeding. Afr. J. Biotechnol., 6: 1848-1853.

Feed Composition Tables for Animals and Poultry Feedstuffs Used in Egypt (2001). Technical Bulletin No.,1, Central Lab. For Food and Feeds(CLFF) Ministry of Agric. Res. Cent. Egypt.

González-Alvarado, J. M., E. JiménezMoreno, R. Lázaro, and G. G. Mateos (2007). Effects of type of cereal, heat processing of the cereal, and inclusion of fiber in the diet on productive performance and digestive traits of broilers. Poult. Sci., 86:1705-1715

Incharoen, T. and P. Maneechote (2013). The effects of dietary whole rice hull as insoluble fiber on the flock uniformity of pullets and the egg performance and intestinal mucosa of laying hens. American Journal of Agricultural and Biological Sciences., 8 (4): 323-329.

Hartini, S.; M. Choct, G. Hinch, A. Kocher, and J. V. Nolan (2002). Effects of light intensity during rearing and beak trimming and dietary fiber sources on mortality, eggproduction, and performance of ISA Brown laying hens. J. Appl. Poult. Res. 11:104-110.

Hetland, H.; B. Svihus, and Å. Krögdahl (2003). Effects of oat hulls and wood shavings on digestion in broilers and layers fed diets based on whole or ground wheat. Br. Poult. Sci., 44:275282.

Hetland, H.; B. Svihus and M. Choct (2005). Role of insoluble fiber on gizzard activity in layers. Worlds Poultry Science J., 60: 415-422.

Hetland, H., and B. Svihus (2007). Inclusion of dust bathing materials affects nutrient digestion and gut physiology of layers. J. Appl. Poult. Res., 16:22-26.
Hussein, M. A. A; Kout Elkloub, M.El. Moustafa; M. K. Gad El-hak and A. M. Abbas (2010). Optimal metabolizable energy and crude protein levels for Sinai laying hens. Egypt. Poult. Sci., (30) (IV): 1073-1095.

Jakobsen, P.E.; S.G. Kirston and S.H. Nilson (1960). Digestibility trials with poultry. 322 Bereting fraforsgs Laboratoriet udgivet of tants Husdyrbugsud Valy - Kaben Haven

Jiménez-Moreno, E., J. M. GonzálezAlvarado, R. Lázaro, and G. G. Mateos (2009). Effects of type of cereal, heat processing of the cereal, and fiber inclusion in the diet on gizzard $\mathrm{pH}$ and nutrient utilization in broilers at different ages. Poult. Sci., 88:1925-1933.

Jiménez-Moreno, E., S. Chamorro, M. Frikha, H. M. Safaa, R. Lázaro, and G. G. Mateos (2011). Effects of increasing levels of pea hulls in the diet on productive performance and digestive traits of broilers from one to eighteen days of age. Anim. Feed Sci. Technol., 168:100-112.

Kalmendal, R., K. Elwinger, L. Holm, and R. Tauson (2011). High-fibre sunflower cake affects small intestinal digestion and health in broiler chickens. Br. Poult. Sci., 52:86-96.

Krause, E.L. and W. Ternes (1999). Bioavailability of the antioxidantive thyme compounds thymol and pcymene2, 3-diol in eggs. Eu. Food Res. Tech., 209: 140-144.

Leeson, S. and J.D. Summers (2001). Digestion and nutrient availability. Page 5 in Scott's Nutrition of the Chicken. Univ. Books, Guelph, Ontario, Canada.

M.A.L.R., Minister of Agriculture and Land Reclamation (2004). Economic Affaris Sector. Agriculture statistics. V. 2 (June) P. 269-328.

Lumeij, J.T. (1997). Avian clinical biochemistry. In: Kaneko JJ, Harvey JW. Bruss ML, eds: Clinical Biochemistry of Domestic Animals. San 
Diego, Calif: Academic press ; PP : 857-884.

Mailer, R. (2006). Chemistry and quality of olive oil. NSW Deparment of Primary Indutries .WWW. dpi.nsw.gov.au.

Mateos, G.G.; R. Lazaro and M.I. Gracia (2002). The feasibility of using nutritional modifications to replace drugs in poultry feeds. Journal Applied Poultry Research., 11:437-452.

Mateos , G.G.; E. Jiménez-Moreno; M.B. Serrano and R.B. Lázaro ( 2012). Poultry response to high levels of dietary fiber sources varying in physical and chemical characteristics. J. appl. Poult. Res., 21 :156-174.

Miller Jones, J. (2004). Dietary fibre intake, disease prevention, and health promotion. Pages 143-159 in Dietary Fibre: Bio-active Carbohydrates for Food and Feed. J. W.

Mohiti-Asli, M., M. Shivazad, M. Zaghari, M. Rezaian and S. Aminzadeh (2012). Effects of feeding regimen, fiber inclusion and crude protein content of the diet on performance and egg quality and hatchability of eggs of broiler breeder hens. Poult. Sci., 91: 3097-3106.

Montagne, L., J. R. Pluske, and D. J. Hampson (2003). A review of interactions between dietary fibre and the intestinal mucosa, and their consequences on digestive health in young non-ruminant animals. Anim. Feed Sci. Technol., 108:95-117.

Newman, R.K., C.F. Klopfensten, C.W. Newman, N. Guritno and P.J. Hofer, (1992). Comparison of the cholesterollowering properties of whole barley, oat bran and red dog in chicks and rats. Cer. Chem., 69: 240-244.

NRC (1994). National Research Council. Nutrient Requirement for Poultry. Ninth Revised Ed. National Academy Press, USA. Perez, V. G.; C. M. Jacobs; J. Barnes; M. C. Jenkins; M. S. Kuhlenschmidt; G. C.
Olgun,O.; and A.O.Yildiz (2015). Effect of dietary Alfalfa meal on performance, egg quality, egg yolk cholesterol and hatchability parameters of quail breeders. Turkish J. of Agri. - Food Sci. and Tec., 3 (3) 103-106.

Razael, M. and H. Hafezian (2007). Use of different levels of high fiber sunflower meal in commercial leghorn type layer diets. International J. of Poult. Sci., 6(6): 431-433.

Perez, V. G.; C. M. Jacobs; J. Barnes; M. C. Jenkins; M. S. Kuhlenschmidt; G. C. Fahey; C. M. Parsons and J. E. Pettigrew (2011). Effect of corn distillers dried grains with solubles and Eimeria acervulina infection on growth performance and the intestinal microbiota of young chicks. Poult. Sci., 90:958-964.

Roberts, S. A.; H. Xin; B. J. Kerr; J. R. Russell and K. Bregendahl (2007). Effects of dietary fiber and reduced crude protein on ammonia emission from laying-hen manure. Poult. Sci. 86:1625-1632.

Rougière, N. and B. Carré (2010). Comparison of gastrointestinal transit times between chickens from $\mathrm{D}+$ and D- genetic lines selected for divergent digestion efficiency. Animal ., 4:11, pp 1861-1872.

Sadeghi1, H.; A. Teimouri Ynsari and Z. Ansari-Pirsarai(2009). Effects of different olive cake by products on dry matter intake, nutrient digestibility and performance of Zel sheep. Int. J. Agr. Biol., 11: 39-43.

Sarikhan, M.;H.A. Shahryar;B. Gholizadeh; M.H. Hosseinzadeh;B. Beheshti and

Serman, V.; N. Mas; V. Melenjuk; F. Dumanovski and Z. Mikulec (1997). Use of sunflower meal in feed mixtures for laying hens. Acta Veterinarian Brno., 66(4):219-227.

Servili.M., Sordini, B., Esposto, S., Urbani, S., Veneziani, G., Maio, I.D., Selvagginin, R. and Taticchi, A. 
(2014). Biological activities of phenolic compounds of extra vigin olive oil: review. Antioxidants Journal. 3:1-23.

SPSS. (2008). SPSS User's Guide Statistics. Ver. 17. Copyright SPSS Inc., USA.

Svihus, B.; I. Juvik; H. Hetland and A. Krogdahl (2004). Causes for improvement in nutritive value of broiler chicken diets with whole wheat instead of ground wheat. Br. Poult. Sci., 45:5560.

Senkoylu, N. and N. Dale (1999). Sunflower meal in poultry diets: a review. World's Poultry Science Journal ., 55(6):153-174.

Shixia,L. and Na WCZ (2006). Effect of Dietary Fibre on Growth Performance and Serum Parameters for Landes Goose [J]. Journal of the Chinese Cereals and Oils Assoc., 3: 041.

Sklan, D., A. Smirnov, and I. Plavnik (2003). The effect of dietary fiber on the small intestines and apparent digestion in the turkey. Br. Poult. Sci. 44:735740 .

Speake, B.K., A.M.B. Murray and R.C. Noble (1998). Transport and transformation of yolk lipids during development of the avian embryo. Progress in Lipid Res., 37: 1-32.

Smits, C.H.M.; G. Annison (1996). Nonstarch polysaccharides in broiler nutrition: towards a physiological valid approach to their determination. Wolrd's Poult. Sci. J., 52: 203-221.

Surai, P.F. (1999a). Vitamin E in avian reproduction. Poult. Avian Biol. Rev., 10: $1-60$.
Svihus, B. (2011). The gizzard: Function, influence of diet structure and effects on nutrient availability. World's Poult. Sci. J., 67:207-224.

van der Aar, P. J., G. C. Fahey Jr., S. C. Ricke, S. E. Allen, and L. L. Berger(1983). Effects of dietary fibers on mineral status of chicks. J. Nutr., 113:653-661.

van Krimpen, M. M., R. P. Kwakkel, C. M. C. van Peet-Schwering, L. A. den Hartog, and M. W. A. Verstegen(2009). Effects of nutrient dilution and nonstarch polysaccharide concentration in rearing and laying diets on eating behavior and feather damage of rearing and laying hens. Poult. Sci., 88:759-773.

Van Scest, P.J.; J.B. Robertson and A. Lewis (1991). Methods of dietary fiber, neutral detergent fiber and nonstaech polysaccharides in relation to animal nutrition. Journal dairy Science., 74:3583-3597.

Varastegani A. and I. Dahlan (2014). Influence of dietary fiber levels on

feed utilization and growth performance in poultry. Journal of Animal Production Advances., 4(6):422-429.

Victor P. Lim Jr.; Jayson J. Juan; Oliver F. Celestino; Joice V. San Andres and Ernesto A. Martin (2013). Beneficial effects of insoluble raw fiber concentration to layer diet. Philipp J Vet Anim. Sci., 39 (1): 43-52.

Vieira S.L.; A.M. Penz Jr ; E.M. Leboute and J.Corteline(1992). A nutritional evaluation of a high fiber sunflower meal. Journal Applied of Poultry Research., 1(4):382-388. 


\section{تأثير مستويات ومصادر مختلفة من الألياف علي الأبلاء الإنتاجي والاقتصادي للاجاج البياض

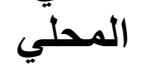

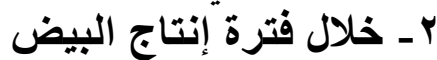

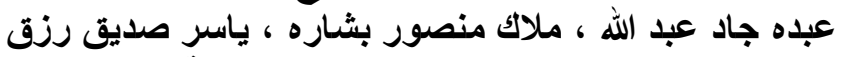

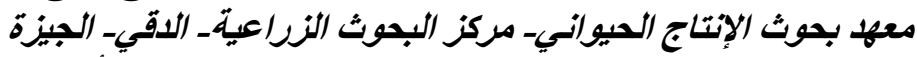

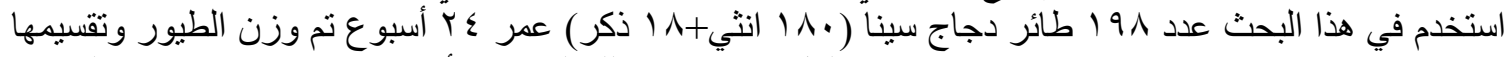

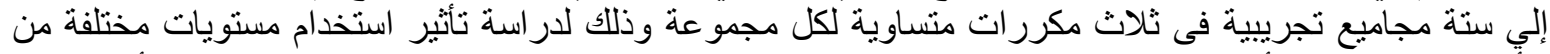

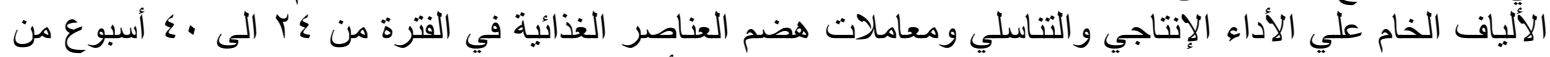

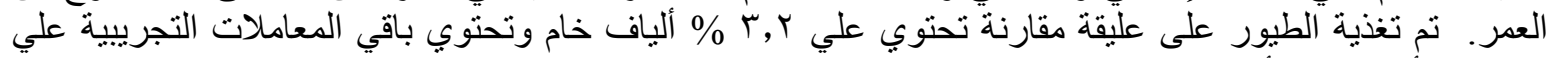

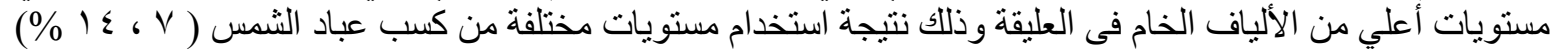

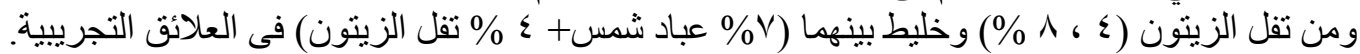

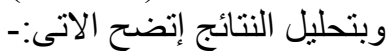

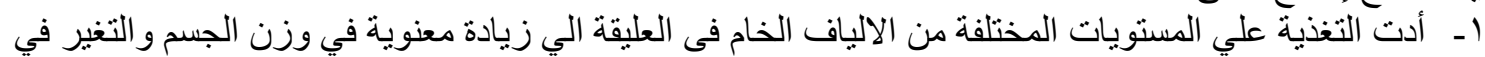

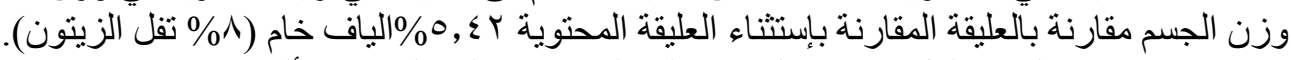

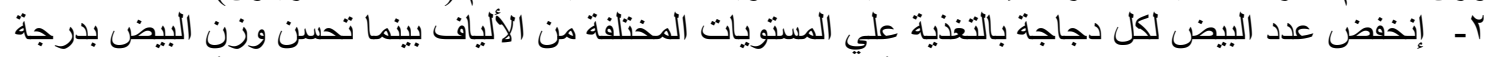

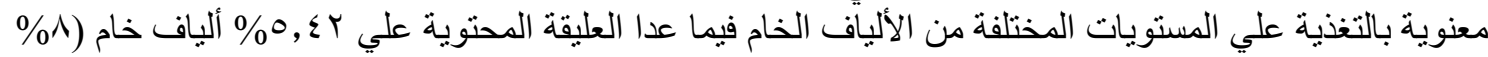

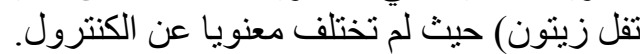

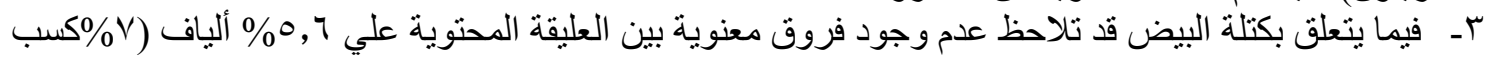

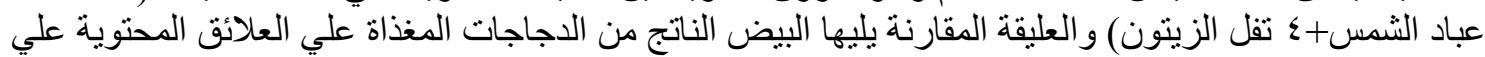

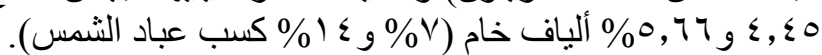

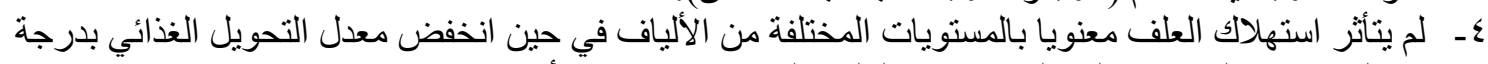

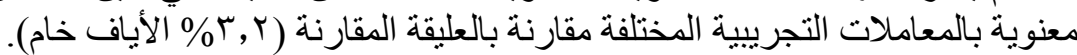

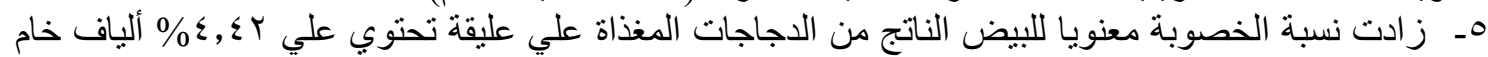

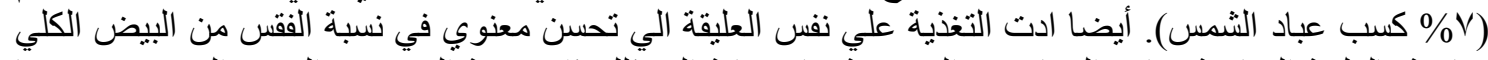

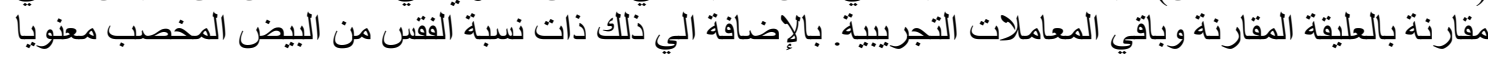

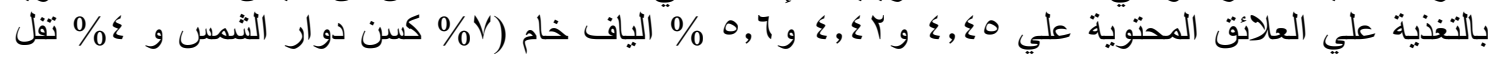
الزيتون و الخليط بينهما) مقارنة بالعليقة المقارنة.

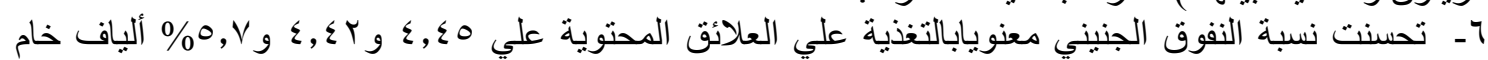

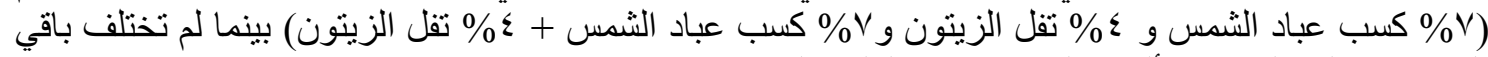

المستويات المختلفة من الألياف الخام مقارنة بالعليقة المقارنة.

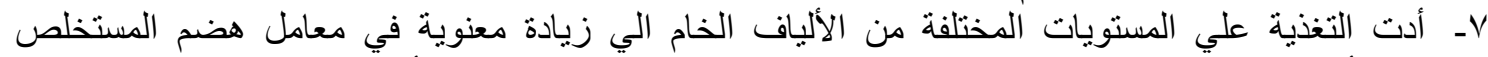

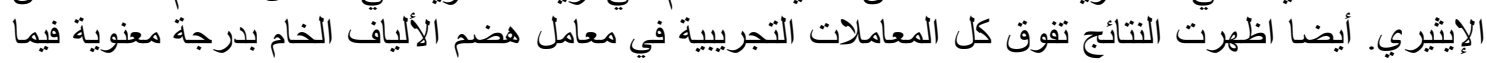

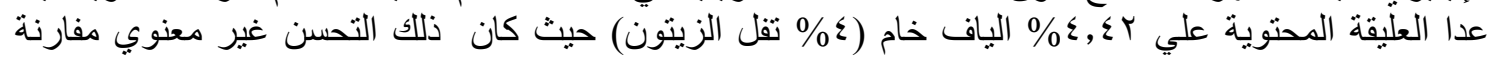
بالعليقة المقارنة.

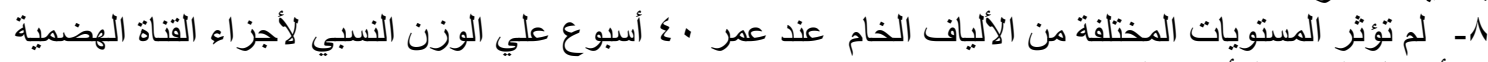
و والأطو ال النسبية للأمعاء الدقيقة.

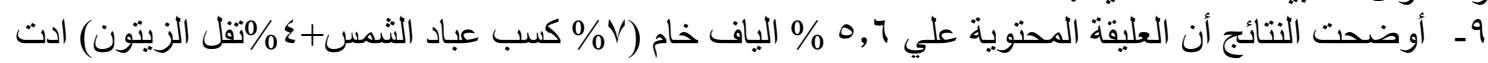

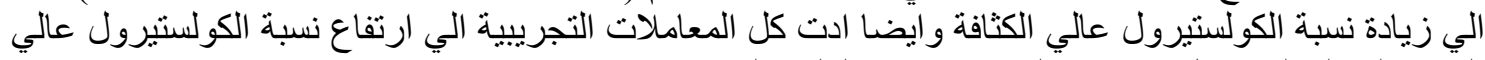

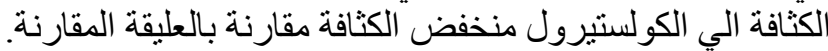

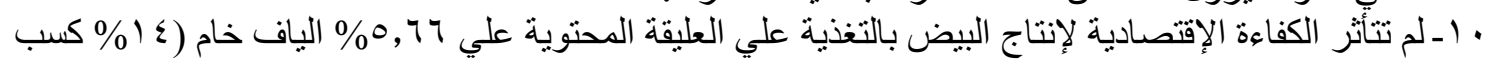

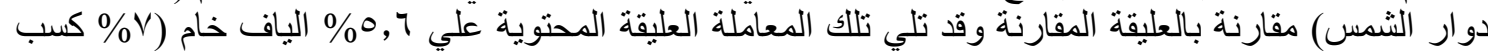

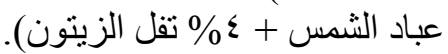

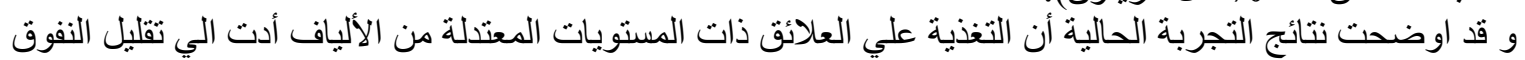

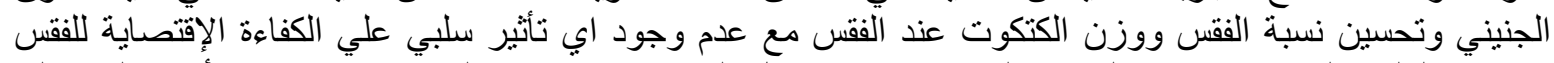

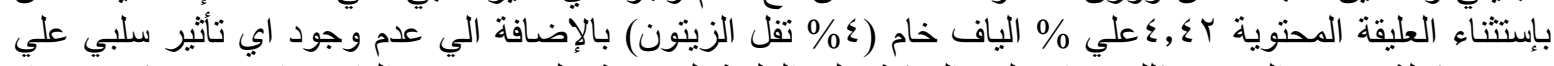

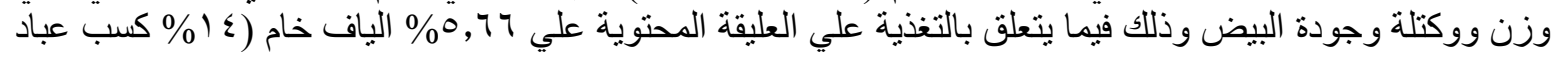

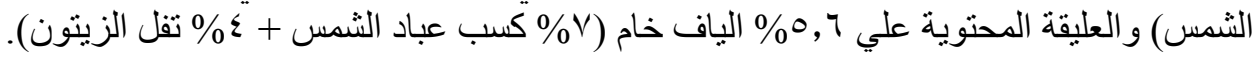

